\title{
Controversies and consensus on the lionfish invasion in the Western Atlantic Ocean
}

\author{
Eira C. Carballo-Cárdenas ${ }^{1}$
}

ABSTRACT. This study investigates how the lionfish (Pterois sp.) invasion of the Western Atlantic Ocean has been socially constructed by natural scientists, the media, and stakeholders associated with various marine protected areas in the Caribbean. By examining the use of data and metaphors by these actors, I identify where invasion discourses converge and diverge. Although consensus exists regarding the non-nativeness, introduction vector, and successful establishment of lionfish throughout the region, I also identify uncertainty surrounding lionfish impact and controversies regarding lionfish management and control. The dominant discourse frames lionfish as a threat and control efforts as a war to keep the enemy at bay, and promotes lionfish hunting and consumption by humans: the "ultimate predators." However, this view is challenged by a coalition that questions the safety, effectiveness, and morality of the practices promoted by the kill-and-eat lionfish coalition. A nascent discourse that frames lionfish as fulfilling the role of overexploited native species, primarily expressed in socioeconomic terms, is shifting lionfish impact perception from negative to positive among some stakeholder groups. Whereas the dominant discourse views humans as helping nature to regain balance through lionfish hunting, a minority coalition views lionfish as part of the ecosystem, where a new equilibrium will be reached. This study shows that scientific data and metaphors, amplified by the media, facilitated initial understanding of the lionfish phenomenon and are used to legitimize claims. In time, however, local knowledge and societal values have intermingled with scientific data, sometimes challenging scientific discourses, and contributing to a richer understanding of the invasion as a social-ecological phenomenon.

Key Words: data; discourse analysis; invasive lionfish; marine protected areas; metaphors

\section{INTRODUCTION}

Species introductions, their impacts, and their management are among the most salient biodiversity conservation issues globally (Vitousek et al. 1996, Mack et al. 2000, McGeoch et al. 2010, Davis et al. 2011). When a species is introduced to a new environment, it engages in complex interactions with the biotic, abiotic, and human components of the recipient ecosystem and may become categorized as invasive (Boonman-Berson et al. 2014). No consensus exists on what a biological invasion is, not even among invasion scientists (Richardson et al. 2000, Valéry et al. 2008, Heger et al. 2013). This lack of consensus is reflected by competing discourses in scientific and public debates on invasive species. Note that the term "invasive" is used throughout the paper for consistency purposes, while recognizing the contested meanings of this expression. See the section titled "Constructing a biological invasion: origin, spread, impact, and control."

At the crux of controversies among invasion ecologists are disparate perspectives on the criteria and terminology used to classify a species as invasive (Colautti and MacIsaac 2004). Also debated are the risks that such species represent for native species (Gurevitch and Padilla 2004, Clavero and García-Berthou 2005) and the acceptable degree of subjectivity and advocacy when ecologists communicate about biological invasions in the public arena (Colautti and Richardson 2009, Young and Larson 2011). Moreover, ecologists have debated with social scientists and philosophers on the rhetoric of ecologists (Simberloff 2003). The latter have been harshly criticized for their use of metaphors that frame invasive species issues in militaristic and xenophobic terms (Subramaniam 2001, Chew and Laubichler 2003, Larson 2005 , 2007a, 2007b, Warren 2007).
Media coverage of biological invasions has similarly been criticized for its hyperbolic language and alarmist metaphors (Gobster 2005, Larson et al. 2005). Recognized as powerful areas of meaning-making in society, science and the media ultimately shape public views, policy, and management of invasive species (Stromberg et al. 2009, Lavoie 2010). As a growing literature has highlighted, a species labeled as invasive is often perceived and valued differently by different people, and these divergent constructions usually lead to management disputes (Perry and Perry 2008, Weeks and Packard 2009, Marshall et al. 2011, Shine and Doody 2011, Dickie et al. 2014). Therefore, understanding stakeholders' plural views and values of the focal species is acknowledged as key for workable management strategies and to minimize conflict (García-Llorente et al. 2008, Schüttler et al. 2011, Estévez et al. 2015).

Increasingly, local communities are participating in invasive species management (Foster and Sandberg 2004, Bryce et al. 2011, Shine and Doody 2011, Ford-Thompson et al. 2012). This is the case for the recent lionfish invasion in the Western Atlantic Ocean (Morris 2012). The present study is a contribution to the body of literature on the management implications of competing discourses on invasive species, with the lionfish Caribbean invasion as case. An ever-increasing number of academic publications on Atlantic lionfish exist from a natural science perspective (Côté et al. 2013, GCFI 2014), but only minor attempts have been made to understand stakeholders' views on this species and its management (Ali 2011, Moore 2012, Scyphers et al. 2014).

This study sets out to investigate how the lionfish invasion has been socially constructed and defined by natural scientists, the 
media, and local stakeholders associated with various marine protected areas (MPAs) in the Caribbean, by examining the use of data and metaphors by these actors. The goal is to ascertain where discourses on lionfish converge and diverge, and whether competing discourses have been implicated in management disagreements. The study is relevant given the growing importance of the lionfish invasion as a conservation and development concern in the region, the participatory nature of lionfish control efforts, and the recognition of MPAs as priority control locations given their high ecological value and conservation-oriented character (Morris 2012, Gómez Lozano et al. 2013, GCFI 2014).

\section{CONCEPTUAL FRAMEWORK}

\section{Constructing a biological invasion: origin, spread, impact, and control}

The analysis of lionfish discourses is positioned against the backdrop of key debates on biological invasions, for which the definition of invasive species is crucial. Classifying a species as invasive is important given the practical consequences that ensue, such as control or eradication programs to mitigate perceived negative impacts. Discussions regarding the definition of invasive species center around the so-called native versus non-native duality, where the biogeographic or origin criterion is paramount in classifying a species as invasive (Richardson et al. 2000, Warren 2007, Valéry et al. 2008). In other words, the species being novel to a region is the only factor considered to classify it as invasive. The rationale is that a non-native species, by virtue of its lack of coevolutionary history within the native environment, possesses traits, e.g., lack of predation, competition, parasitism, that may confer it advantage over local species and facilitate its domination in local communities (Simberloff 2005). Advocates of the origin criterion are concerned with the unprecedented rate at which humans redistribute species because of increased human travel and globalized trade and transport (Carlton and Geller 1993, Vitousek et al. 1996). Evidence to support the origin criterion primarily consists of data that establish the species identity, its origin, and the vector of introduction. Terminology used to designate this foreignness includes terms such as nonindigenous, alien, foreign, exotic, and immigrant (Wong 2002, Falk-Petersen et al. 2006).

Various ambiguities complicate the categorization of a species as invasive based solely on its origin. Variable spatial and temporal scales are applied in deciding where and when a species is invasive (Richardson et al. 2000, Hall 2003, Donlan and Martin 2004). Moreover, according to the origin criterion, native species that become dominant and "encroach" in their native environment do not qualify as invasive. To account for these perceived limitations, the "spread" and "impact" criteria have been advanced to complement the definition of invasive species.

The potential of a species to spread over a long distance rapidly and colonize a large area is viewed by proponents of this criterion as a defining characteristic of an invasive species, regardless of its origin (Richardson et al. 2000, Daehler 2001). The logic is that because populations of most non-native species do not or only minimally expand beyond their sites of introduction, they do not meet the spread criterion and hence should not be classified as invasive. Rapid distribution of a species, through population growth and expansion over a large area, is thought to occur at the expense of other (native) species. In this way, spread is associated to the notion of harm and linked to the impact criterion. Opponents to this line of thinking claim that long-distance spread may have negligible impact on the new environment; in other words, they think that spread is not correlated to impact (Ricciardi and Cohen 2007). Data that underpin the spread criterion include species numbers and location (how many? where?), reproduction rates, growth rates, and in the case of fish, larval dispersal and recruitment rates. Terminology used in relation to the spread criterion include militaristic metaphors like colonizer, invader, and natural enemy (Chew and Laubichler 2003).

Environmental and societal costs, including human health and economic loss, associated with a number of successful invaders are widely acknowledged (Vitousek et al. 1996, Pimentel et al. 2005). Nonetheless, the impact criterion has been strongly criticized by a group of scholars for its nebulous, undefined, and subjective nature (Daehler 2001, Sagoff 2005), because qualifying and quantifying the effects of invasive species both in ecological and social terms ultimately rest on value judgments. Evidence regarding impact in ecological terms includes data on distribution, density, and in the case of fish, per capita effect of the individual invader, for which "effect" remains difficult to establish (Parker et al. 1999). Data that demonstrate impact in socioeconomic terms include opportunity costs due to invasive species-driven population decline or extinctions of commercially exploited species, and data on the costs of control programs. Terminology used for harmful species include pest, transformer, biological pollution, and infestation (Davis and Thompson 2000, Wong 2002, Larson 2008).

Although ecological damage caused by an introduced species classified as invasive may be recognized, the same species may also provide food, ornamental benefits, or recreational benefits as well as other ecological services (Robbins 2004, Weeks and Packard 2009, Dickie et al. 2014). This ambiguity confounds the use of the impact criterion, with its negative connotation, in classifying a species as invasive. Moreover, perceptions of a species as "good" or "bad" may change through time and across stakeholder groups, with implications for management decisions (García-Llorente et al. 2008, Stromberg et al. 2009). Control of invasive species may trigger controversies because of high economic costs, uncertainties, divergent stakeholder interests, and ethical concerns (Messing and Wright 2006, Haider and Jax 2007, Evans et al. 2008, Nuñez et al. 2012). Data sought to justify specific control methods include cost-benefit analyses and assessments of potential efficacy and side effects. Control metaphors used include war, anti-immigration, epidemic, and catastrophe (Wong 2002, Larson et al. 2005, Zinken 2007, Nerlich and James 2009).

\section{Discourses and invasive species management}

Discourse is defined as "a meaning of a phenomenon shared by a small or large group of people on the local, national, international or global level" (Arts et al. 2012:912). Referred to as a discourse coalition, a group sharing the same meaning of a phenomenon is an internally diverse set of actors that "strives for hegemony by trying to empower its definition of reality on the basis of credibility, acceptability and trust" (Arts et al. 2012:912). A storyline is a central idea that condenses a discourse in a simple, succinct way and sometimes replaces complex debates by clustering knowledge. As use of storylines increases, they acquire a ritual character and become a discursive cement that keeps a 
Table 1. Selected marine protected areas. Data from MPA Global (http://www.mpaglobal.org/) and MPAtlas (http://www.mpatlas.org/); ecoregions after Spalding et al. (2007).

\begin{tabular}{|c|c|c|c|c|}
\hline $\begin{array}{l}\text { MPA } \\
\text { (designation date) } \\
\end{array}$ & $\begin{array}{c}\text { Total Area } \\
\left(\mathrm{km}^{2}\right)\end{array}$ & Governance & $\begin{array}{l}\text { Caribbean } \\
\text { Ecoregion } \\
\end{array}$ & $\begin{array}{c}\text { Lionfish first } \\
\text { sighted }\end{array}$ \\
\hline Florida Keys National Marine Sanctuary (1990) & 9,845 & State-led & Floridian & 2009 \\
\hline Sian Ka'an Reefs Biosphere Reserve (1998) & 349.3 & State-led & Western Caribbean & 2009 \\
\hline Bonaire National Marine Park (1979) & 27 & NGO & Southern Caribbean & 2009 \\
\hline Curaçao Underwater Marine Park ${ }^{\dagger}$ (1983) & 10.4 & NGO & Southern Caribbean & 2009 \\
\hline St. Maarten "Man of War Shoal" Marine Park (2010) & 31 & NGO & Eastern Caribbean & 2010 \\
\hline Saba National Marine Park (1987) & 13 & NGO & Eastern Caribbean & 2010 \\
\hline St. Eustatius National Marine Park (1996) & 27.5 & NGO & Eastern Caribbean & 2010 \\
\hline
\end{tabular}

${ }^{\dagger}$ Although this MPA is listed by international MPA databases, it has not been designated by law and lacks effective management, and is therefore considered a "paper park" (http://www.carmabi.org/nature-management/curacao-marine-park).

coalition together. A discourse coalition draws on scientific evidence, i.e, data, to make itself persuasive and legitimate, and draws on metaphors to convey meaning (Irwin 1995, Hajer 1997).

Data play a key role in substantiating claims in invasive species debates (Wilcove et al. 1998). However, practices of data production, interpretation, and use are also contested (Stromberg et al. 2009, Crall et al. 2010, Lavoie 2010, Davis et al. 2011, Boonman-Berson et al. 2014). For instance, different interpretations of the same data sets have led to opposing assessments of the impact of invasive species on native species (Gurevitch and Padilla 2004, Clavero and García-Berthou 2005).

Metaphors allow people to conceptualize the unfamiliar in terms of the familiar (Lakoff 1993, Maasen et al. 2001). Metaphors are mental models that aid, through a linguistic expression, our understanding of one mental domain in terms of another. Metaphors are ubiquitous in science (Maasen et al. 2001), and in ecology, metaphorical frames are used to conceptualize nature and interpret invasive species (Cuddington 2001, Chew and Laubichler 2003, Keulartz and van der Weele 2008).

Two metaphors, nativism and cosmopolitanism, represent extreme positions with respect to how invasive species and their management are viewed according to core beliefs and values in conservation (Callicott et al. 1999, Keulartz and van der Weele 2008). Nativism conceptualizes nature as pure and in harmony if consisting of species that originate in or belong to a certain space and if these species' composition and numbers remain roughly constant (Cuddington 2001). Nature is believed to be fragile and vulnerable to humans' destructive influence, and hence in need of protection to preserve its biological integrity and balance (Peretti 1998, Callicott et al. 1999, Cuddington 2001, Davis et al. 2011). Restoration in nature is analogous to restoration in the visual arts, with the aim of resembling as much as possible the "original composition" of a pristine landscape/seascape, in which nonnatives are unwelcome (Keulartz and van der Weele 2008). Handson management is thus necessary to prevent the introduction of foreign species, or if that fails, to eradicate them. Cosmopolitanism, on the other hand, sees non-natives as a component of an inexorable process of change and recombination of a robust nature, and calls for acceptance of these novel ecosystems (Soulé 1990, Keulartz and van der Weele 2008, Davis et al. 2011, Graham et al. 2014, Graham and Hicks 2015). A hands-off management stance is advocated here, with human intervention not warranted except for elimination of "the most offensive exotics" (Soulé 1990:235).
Between these two poles, other metaphors exist along a continuum such as nature as a patient that can be cured (rehabilitation) or nature as a machine/factory that can be repaired (reparation), where the role that the species plays in the whole is what counts, therefore conferring more flexibility regarding non-natives. Although in the rehabilitation metaphor, the criterion of biological integrity is important to the health concept, the function of the species in the ecosystem is emphasized, not its origin. The ritual and communal character of the "healing art" (an euphemism for elimination of invasive species through sacrificial rituals) distinguishes this view from the reparation metaphor, which regards nature as a set of resources with cash value, where foreign species are "so to speak, entitled to a green card as long as they do their job" (Keulartz 2008:249). Figure 1 depicts the conceptualizations of nature through these metaphors and implications for non-native species management.

\section{METHODS}

\section{Study approach and setting}

Discourse analysis (Hajer 1997) was applied to various linguistic data sources (Wetherell et al. 2001): scientific literature, online media, lionfish management documents, and interviews. The scientific construction of the invasion was taken as a starting point of the analysis. Then an examination of how the media reported on the issue and how local stakeholders interpreted the invasion was conducted.

MPAs located in the Caribbean, a "major global marine biodiversity hot spot" (Miloslavich et al. 2010:1), were selected as setting because they exemplify the tensions between conservation efforts and invasive species. Purposive sampling (Bryman 2012) was used to identify the specific MPAs for the study. MPA selection proceeded as follows: academic/grey literature and online material (MPA websites, press releases) provided an overview of the MPAs where lionfish was a management issue. Sites were selected based on (1) existing contacts with MPA staff/ stakeholders, which facilitated access to these and other informants, (2) first lionfish sightings reported around the same period, and (3) spread in geographic location, sizes, and governance modes to ensure a diverse sample (Table 1). Sites selected are multiple-use MPAs.

\section{Data collection}

Primary data sources were semistructured interviews conducted between January and March 2013. Relevant informants were those with a stake in the MPA and potentially engaged in lionfish 
Fig. 1. Conceptualizations of nature and implications for non-native species management (based on Callicott et al. 1999 and Keulartz and van der Weele 2008).

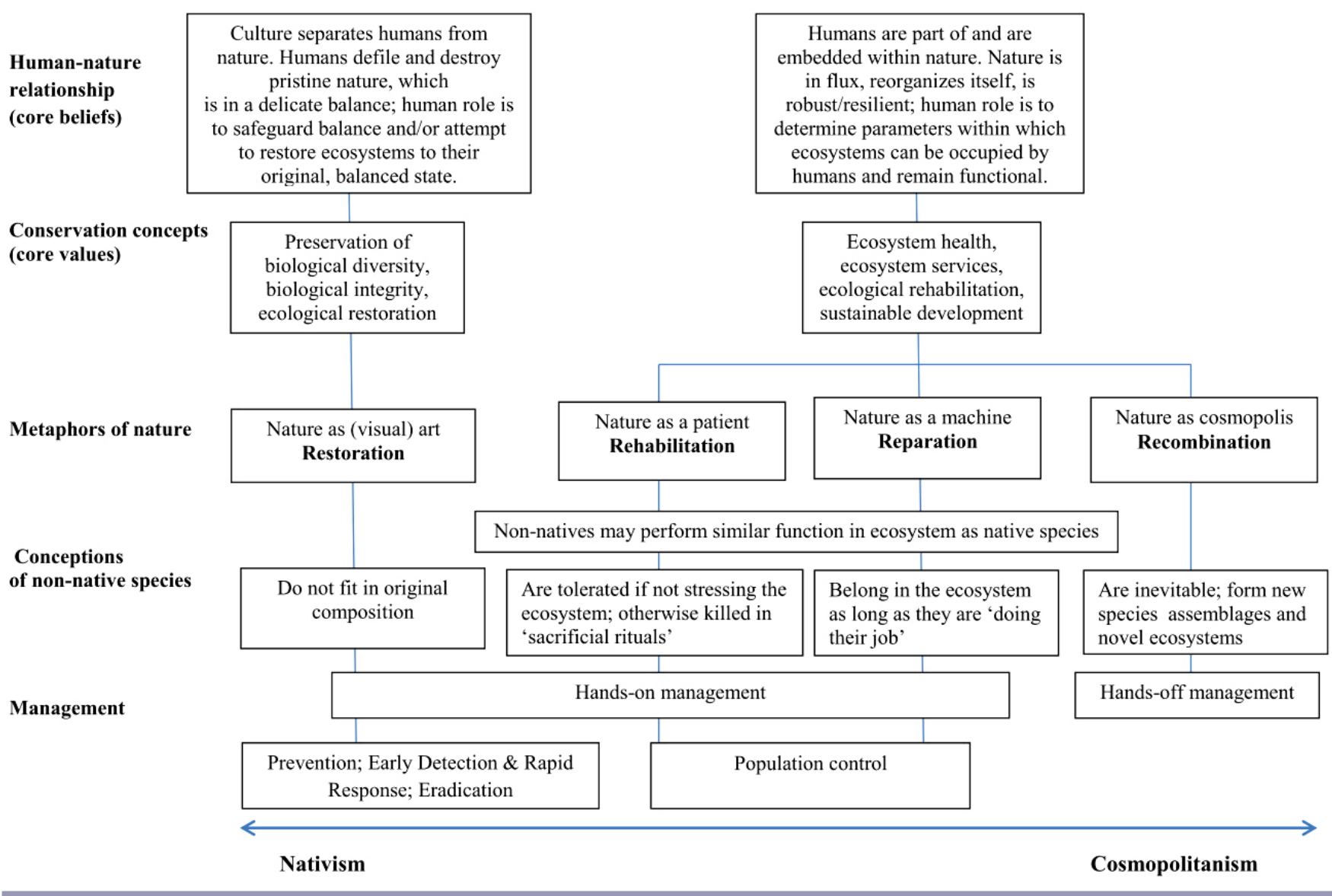

management. Referred to as local MPA stakeholders, the sample included MPA staff, government officials, nongovernmental organization (NGO) representatives, scientists, dive tourism operators, recreational and commercial fishers, and other resource users (Appendix 1). After locating potential respondents through a mix of online searches and snowball techniques (Bryman 2012), interview appointment requests were sent by email. On Bonaire and St. Maarten, opportunistic sampling was carried out by walking along the beach and requesting interviews from staff present at the encountered dive shops. On St. Eustatius and Saba, a few fishermen at work were also interviewed on-site. For this reason, the length of some unplanned interviews was short, but the interviews provided rich data from key stakeholders. Telephone and face-to-face interviews (average length of 36 minutes, range of 8-95 minutes), based on the topic list shown in Appendix 2, were taped and transcribed. Participant observation of a lionfish removal activity organized by a dive operator was performed on Curaçao.

Scientific articles were selected based on their contribution to the origin, spread, impact, and control components of the analysis, using Google Scholar citation numbers and cross-referencing patterns as indication of the article's influence in the debate. Online news reports were selected based on geographical spread, representing the studied ecoregions; language, i.e., English, Spanish, or Dutch as spoken in the selected MPAs; and scope, including large news media broadcasters with an international audience as well as small, local news providers. In selecting scientific and media data sources, attention was given to the period covered to provide an overview of discourse formation in time, up to 2013. Also, during the interviews stakeholders were prompted to provide a chronological sequence in their lionfish accounts.

\section{Data analysis}

Data sources were imported into Atlas.ti for deductive and inductive coding (Fereday and Muir-Cochrane 2008). Inductive coding is a data-driven process that entails careful reading and rereading of the data to identify themes, i.e. discourses, whereas deductive coding applies a code template "as a means of organizing text for subsequent interpretation," i.e., distinguishing discourse coalitions based on argumentations and teasing out arguments to identify their constituent data and metaphors (Fereday and Muir-Cochrane 2008:83). In total, 167 documents were coded: 50 scientific articles, 7 lionfish assessment and management plans, 58 online news reports, and transcripts of 52 interviews, including group interviews ( 80 respondents in total). 


\section{RESULTS}

Ecologists and the media univocally define lionfish as invasive based on the three criteria of origin, spread, and impact, characterizing lionfish as a threat and calling for population control through targeted removals. Most MPA stakeholders interviewed aligned themselves with this dominant discourse, but some divergence was revealed in respondents' views of spread, impact, and the defensibility of control measures, including human consumption of lionfish, with implications for management in some of the MPAs studied.

\section{Origin}

Storyline: Indo-Pacific lionfish most likely introduced through aquarium releases in Florida

Scientists from the U.S. National Oceanic and Atmospheric Administration (NOAA) published the first scientific article on the occurrence of lionfish in the Western Atlantic Ocean (Whitfield et al.2002). This article qualified the lionfish as invasive based on its foreignness and dispersal throughout the U.S. East Coast and Bermuda. The non-nativeness of lionfish in the Western Atlantic Ocean was quickly accepted as a fact, because this fish was known to occur in the Western Pacific and Indian oceans (Schultz 1986), but was never observed in Atlantic waters before the 1980s. This absence of data on lionfish sightings prior to the 1980 s in the Western Atlantic Ocean was equated to nonnativeness.

Lionfish are conspicuous in their coloration patterns, fleshy tentacles above eyes and around the mouth, large pectoral fins, and venomous spines, and are thus easily recognizable by scientists and resource users. In early investigations from 2000 to 2004, visual identification and description of morphology and meristics (quantification of fish traits such as fin spines) were the primary data used to establish lionfish identity. In subsequent stages, genetic data were used to distinguish between the two sister species, Pterois volitans and P. miles, caught throughout their novel range to reconstruct lionfish expansion and to trace the origin of the parent populations to Indonesia and the Philippines (Hamner et al. 2007, Freshwater et al. 2009).

How did the lionfish arrive at the Western Atlantic Ocean in the first place? Various explanations were considered by scientists (Hare and Whitfield 2003). Initial hypotheses of natural dispersal through the Panama Canal or across the Atlantic from the Mediterranean Sea, where lionfish had also been sighted (Golani and Sonin 1992), were soon discarded because the distance was deemed too large and the ecological barriers, insurmountable. Moreover, later studies showed that genetic data did not match the data from those areas.

Concurrently, evidence pointing to a human-mediated introduction accumulated. Ship ballast water is the most common introduction vector of marine species and was a logical candidate. Nonetheless, aquarium trade was eventually identified as the most likely vector for lionfish and other marine tropical fish introductions. This claim was substantiated by multiple data sources, including "a large spatially explicit marine fish database to show that there are a surprising number of non-native fishes on the reefs of southeast Florida, USA.... Data on international shipping patterns and marine fish imports were used to evaluate the culpability of these 2 vectors. Our results suggest that the introductions are the result of aquarium releases" (Semmens et al. 2004:239). The marine fish data used have been compiled by the Reef Environmental Education Foundation (REEF), an NGO based in Florida, through its sport diver volunteer fish surveys since 1993 and its online "exotic species reporting page" since 2002 (http://www.reef.org).

The National Geographic News of June 2004 (Pickrell 2004) was the first to feature a story that linked the aquarium and ornamental species industry to non-native species introductions worldwide, including the lionfish case. The story summarized two scientific articles published that year (Padilla and Williams 2004, Semmens et al. 2004) that encouraged measures to prevent further non-native species introductions into aquatic ecosystems in line with nativism. In subsequent reports on lionfish, the media consistently referred to its non-nativeness in headlines such as "Lionfish: Born in the Wrong Sea," "New Pirate of the Caribbean Invades from Pacific," and "Unwelcome Visitors."

The full mechanism through which lionfish were introduced into the Western Atlantic Ocean will probably never be known, but a combination of intentional and accidental releases from Florida aquariums are the most plausible explanations according to scientists and the media. Intentional releases refer to pet owners who no longer wish to keep lionfish in their tanks. Accidental releases refer to a popular account that links a few lionfish sighted in 1992 in Biscayne Bay, Florida, to Hurricane Andrew's destruction of a beachside aquarium. However, the first documented lionfish sighting dates from 1985 in Dania Beach, Florida (Morris and Akins 2009), with the specimen being preserved by the U.S. Geological Survey (Betancur-R et al. 2011) The first time a link was suggested between Hurricane Andrew and lionfish was in 1995 (Courtenay 1995), but Courtenay said to a reporter in 2010 that he would like to "put this idea to rest.... It was second-hand information... which unfortunately continues to spread, so that Andrew is often mentioned as the reason for the catastrophic lionfish invasion" (Morell 2010).

MPA stakeholders were cognizant of the foreign origin of lionfish, often referring to the time when "this fish arrived here," a period characterized by fear of the new species. Respondents reported that they gradually got used to the presence of lionfish in their waters. The introduction vector and mechanism did not feature prominently in respondents' accounts.

\section{Spread}

Storyline: Lionfish are everywhere

Semmens et al. (2004) were "surprised" by the large numbers of non-native fishes they found because before that time establishment of introduced marine fishes was considered rare. Lionfish sighting data indicated that lionfish had the potential to survive and reproduce in their new environment and to rapidly colonize a large area. After the first lionfish sightings in eastern Florida, several years passed before verified reports were received. Between 2000 and 2002, lionfish observations were documented along the U.S. eastern seaboard in Florida, Georgia, North Carolina, and New York, and in Bermuda, about $1000 \mathrm{~km}$ from Cape Hatteras, North Carolina. In 2004 lionfish were observed in the Bahamas, more than $1500 \mathrm{~km}$ south of Bermuda, and in less than a decade lionfish expanded into the rest of the Caribbean and reached South America (Schofield 2009, 2010). 
The most crucial data used by scientists to underpin their application of the spread criterion were sighting data sets, predominantly the U.S. Geological Survey-Nonindigenous Aquatic Species Database (Schofield et al. 2015). This publicly accessible database, accompanied by a real-time point distribution map, includes a total of 5609 sightings from scientists and nonscientists from the entire region where lionfish have been observed as of August 20, 2015. The database, with REEF as important data contributor, enabled tracking lionfish expansion as it unfolded, for the first time documenting the rapid spread of a non-native fish in a novel range. Combined with this distribution data set, abundance and density estimates at various sites illustrated the extent of lionfish invasiveness.

The media attested that "lionfish ... [were] showing up everywhere" (Associated Press 2008). A respondent from Florida stated: "As soon as the first one was seen it was very big news... through Florida." In Sian Ka'an, the Research and Monitoring Coordinator stated:

\section{Injust one year, the lionfish has established and prospered throughout the coast and islands of the states of Quintana Roo and Yucatan, including...Sian Ka'an Reefs Biosphere Reserve... Just for the Ascención Bay area..., there are records of more than 2120 dead specimens, ranging from 3 to $32 \mathrm{~cm}$ in length, plus 1000 sightings". (Gómez 2010)}

Data on sightings (numbers and location), captured lionfish, size, and stomach content were collected in all MPAs studied. MPAs' data sets were made possible through the participation of local divers and fishers in data and specimen collection.

The reproductive characteristics of lionfish have been identified by ecologists as key to its rapid and wide-ranging spread: lionfish may become sexually mature within their first year of life, present yearlong spawning at a frequency of more than two million eggs annually, and reproduce by releasing free-floating egg masses that are dispersed by ocean currents and subsequently develop into planktonic larvae (Morris and Whitfield 2009). Ecologists investigated other factors that enabled this rapid dispersal: those inherent to lionfish biology, such as antipredatory defenses, distinctive predatory behavior, low parasitism, and ecological flexibility including a generalist diet, and those inherent to the recipient ecosystems, such as prey naïveté, weak competitors, and overfished native predators possibly naïve to lionfish (Côté et al. 2013).

For the media, the fecundity and ubiquity of lionfish are integral to their portrayal of this species as invasive. All media stories examined either allude to scientific studies or directly quote scientists and numbers, albeit with some variation from the original data source, in describing lionfish spread to their audience, for instance: "The facts about lionfish are frightening. A female can produce 30,000 eggs every four days" (Ecott 2011). Next to fact reporting, vivid imagery is used such as in this quote from a scientist: "It's like an oil spill that keeps reproducing and will keep reproducing forever" (Shogren 2013). Most respondents had also witnessed a rapid increase in lionfish numbers and size in their waters. However, some dive operators from Saba and St. Eustatius asserted that, based on their own daily observations, lionfish populations in those MPAs were not surging as in other areas. These individuals suggested that lionfish were controlled by local environmental conditions and, possibly, native predators.

\section{Impacts}

Storyline: That fish eats everything; the lionfish is a formidable foe

Because establishment of non-native marine fishes in new ranges was considered uncommon up to 2004, effects of newcomers on marine ecosystems were largely unstudied and unknown. Given the ecological role of lionfish as predator, scientists expressed their concern about possible effects on populations of potential prey and competitors since the first studies on Atlantic lionfish were published. Lack of detailed data on lionfish diet, however, precluded any assessment at that point. The tone of the discourse between 2002 and 2006 was still speculative. During this period negative effects on the ecosystem were considered limited because of the small lionfish numbers observed in locations where lionfish had been sighted (Whitfield et al. 2002, Ruiz-Carus et al. 2006).

After 2007 the tone of the scientific discourse shifted from cautious to alarmist following reports that in some sites along the U.S. coast lionfish were starting to dominate native communities and in the Bahamas, "record lionfish densities" were documented (Whitfield et al. 2007, Green and Côté 2009). Also, data from stomach content analysis and foraging studies showed the wide variety of fish and crustacean prey ingested by lionfish, including ecologically and economically important species (Morris and Whitfield 2009). Higher feeding rates and growth rates were measured in Atlantic lionfish relative to lionfish in their native range. The study by Albins and Hixon (2008) in experimental reefs in the Bahamas affords what has become perhaps the mostreferred-to ecological impact data in the lionfish discourse, by scientists and nonscientists alike:

\section{Lionfish caused significant reductions in the recruitment of native fishes by an average of 79\% over the 5 week duration of the experiment. This strong effect on a key life stage of coral-reef fishes suggests that invasive lionfish are already having substantial negative impacts on Atlantic coral reefs. (Albins and Hixon 2008:233)}

Although no studies have quantified the effect of lionfish on native fish recruitment in natural reefs, an American expert interviewed for a popular TV show in the United States used Albins and Hixon's data to claim that:

\section{In our waters these fishes are consuming everything. They eat everything on a reef. You have a beautiful little patch reef covered with a rainbow of fish and you come back after a lionfish has been there for five weeks and $80 \%$ of those fish are gone. (CBS 2013)}

Two other Bahamas studies linked lionfish to a reduction of native fishes biomass and diversity in coral reefs, which in the latter case preceded a shift to algal dominance (Lesser and Slattery 2011, Green et al. 2012). Meanwhile, data accumulated on various aspects of lionfish biology. The fish were observed in a great variety of habitats (reefs, mangroves, rocky bottoms, seagrass beds, estuaries), showing high range tolerance to depth (1 $\mathrm{m}$ up to $>300 \mathrm{~m}$ ), temperature, and salinity (Kimball et al. 2004, Claydon et al. 2012, Jud et al. 2015). From 2008 onward, various scientific studies called for action in the form of lionfish removals 
Table 2. Scientific discourse formation on Western Atlantic lionfish (Pterois sp.): from speculation to characterization as a threat and advocacy of lionfish removal and consumption.

\begin{tabular}{|c|c|c|c|}
\hline Time & Terminology \& framing & Quotes from influential scientific studies on lionfish & $\begin{array}{l}\text { Metaphors } \\
\text { of Nature }\end{array}$ \\
\hline $\begin{array}{l}2002- \\
2006\end{array}$ & $\begin{array}{l}\text { Introduced } \\
\text { Exotic } \\
\text { Nonindigenous } \\
\text { Non-native } \\
\text { Invasive } \\
\text { Of concern } \\
\text { Exotic } \\
\text { Established } \\
\text { Potential danger } \\
\text { Potential for harmful } \\
\text { effects }\end{array}$ & $\begin{array}{l}\text {...the introduction of lionfish along the [SE US] coast is of concern because a number of } \\
\text { species at a similar trophic level are overfished and the overall fish fauna is already changing } \\
\text { (Whitfield et al. 2002:290). } \\
\text { A surprising number of non-native fishes on the reefs of southeast Florida...[pose] a } \\
\text { significant threat to coastal ecosystems and present a rare opportunity for proactive } \\
\text { management of marine-species introductions, provided managers and scientists act quickly } \\
\text { (Semmens et al. 2004:243). } \\
\text { Lionfish could pose a threat to Florida's fishermen, divers, and wildlife inspectors because it } \\
\text { is venomous and because the general public may not be aware of that fact... (Ruiz-Carus et } \\
\text { al. 2006:388). } \\
\text { The impact of red lionfish on populations of potential prey and competitors cannot be } \\
\text { assessed without detailed data on food habits. Also, we can only speculate on the potential } \\
\text { predators... (Ruiz-Carus et al. 2006:388). }\end{array}$ & $\begin{array}{l}\text { Nativism } \\
\text { (but no call } \\
\text { for action, } \\
\text { except by } \\
\text { Semmens et } \\
\text { al. 2004) }\end{array}$ \\
\hline $\begin{array}{l}2007- \\
2009\end{array}$ & $\begin{array}{l}\text { Invasive } \\
\text { Non-native/ } \\
\text { Nonindigenous } \\
\text { Major concern } \\
\text { Voracious predator } \\
\text { A serious threat } \\
\text { Far-reaching effects } \\
\text { Threaten human health } \\
\text { Impacts expected to be } \\
\text { extreme } \\
\text { Looming threat of marine } \\
\text { invasive species }\end{array}$ & $\begin{array}{l}\text { This threat is likely to increase as lionfish abundance increases and may cause native species } \\
\text { displacement to sub-optimum habitats... The high number of lionfish now present in the } \\
\text { ecosystem increases the potential for cascading impacts throughout the food chain (Whitfield } \\
\text { et al. 2007:61). } \\
\text {...it would be prudent for affected nations to initiate targeted lionfish control efforts as soon } \\
\text { as possible... Recovering and maintaining healthy populations of potential native predators } \\
\text { of lionfish, such as large grouper and sharks, may also help reduce the deleterious effects of } \\
\text { these voracious invasive predators (Albins \& Hixon 2008:237). }\end{array}$ & $\begin{array}{l}\text { Nativism } \\
\text { Call for } \\
\text { action: } \\
\text { Restoration/ } \\
\text { Rehabilitation }\end{array}$ \\
\hline $\begin{array}{l}2010- \\
2013\end{array}$ & $\begin{array}{l}\text { Alien/Aggressive } \\
\text { predator/Pest } \\
\text { Alarming dispersion } \\
\text { Alarming invasive species } \\
\text { Alter balance of natural } \\
\text { habitat } \\
\text { Unprecedented disruption } \\
\text { to reef diversity and } \\
\text { function } \\
\text { Ecologically harmful/ } \\
\text { Damaging/Catastrophic/ } \\
\text { Unprecedented/ } \\
\text { Destructive/Most severe } \\
\text { marine finfish invasion in } \\
\text { the region's history } \\
\text { Substantial threat to } \\
\text { native coral-reef fish } \\
\text { Potential to devastate the } \\
\text { fragile economic sectors } \\
\text { existing in the Caribbean }\end{array}$ & $\begin{array}{l}\text { Lionfish are the first marine fish known to invade the [WA] and Caribbean Sea, and have the } \\
\text { potential to add additional stress to an environment already compromised by overfishing, } \\
\text { pollution and climate change (Arias-Gonzales et al. 2011:917). } \\
\text { The results obtained in the model highlight the need for immediate management actions to } \\
\text { control lionfish populations. It is unlikely that it will be possible to eradicate this piscivorous } \\
\text { invader from the reef systems of the Atlantic, but the model suggests that with an intensive, } \\
\text { long term management control, the population of this species could probably be controlled } \\
\text { (Arias-Gonzales et al. 2011:924). } \\
\text { A control strategy...involved promoting lionfish as a food fish, especially in the Caribbean } \\
\text { and some [MPAs] where high densities of lionfish are easily and inexpensively accessed } \\
\text { (Morris et al. 2011:22). } \\
\text {... It should be noted that the same seafood safety advisories promulgated for native reef } \\
\text { fishes, such as ciguatera poisoning, should also be observed for lionfish. (Morris et al. } \\
\text { 2011:25). }\end{array}$ & Rehabilitation \\
\hline
\end{tabular}

to control populations, calls that were echoed by REEF and the governmental agencies with remit on protected areas in Mexico (Comisión Nacional de Áreas Naturales Protegidas [CONANP]) and the United States (NOAA), which have led efforts to develop a regional management strategy (Morris 2012). Lionfish were now perceived as a threat to stock-rebuilding and reef conservation efforts, with possible repercussions for the fisheries and tourism sectors. Moreover, the fish's venomous spines were considered a public health risk for fishers, swimmers, snorkelers, and divers.
Marine managers, in collaboration with scientists, initiated campaigns to inform the public about "The lionfish invasion!" with warnings such as "Look but don't touch!" (Ali 2011, NOAA 2011). Overall, the message conveyed by scientists and the media was gloomy and expressed through a vocabulary of calamity. In the media's militaristic terms, the war was declared on lionfish, "a formidable foe" (Cocking 2013). Table 2 shows the time course of the scientific discourse, and Table 3 shows examples of media headlines. 
Table 3. Media discourse on Western Atlantic lionfish (Pterois sp.).

\begin{tabular}{l}
\hline Examples of media headlines on lionfish \\
Freed Pet Fish Threaten Native Species, Study Says
\end{tabular}

Freed Pet Fish Threaten Native Species, Study Says

A Spiny Invader Proliferates in L.I. Waters, and Scientists Wonder About Its Impact

Lionfish: Born in the Wrong Sea

Poisonous Lionfish Invade Caribbean, Head Up Eastern Seaboard

Newcomer to Keys is Unwelcome, Uncouth

Beautiful but Lethal Lionfish: Wanted Dead or Alive

[Translated from the Spanish]

Influx of Lionfish a Threat to Native Marine Life, Experts Say

New Pirate of the Caribbean Invades from Pacific

Fighting Lionfish Necessary for Coral [Translated from the Dutch]

Red Lionfish (Pterois sp). A New Threat for the Mesoamerican Reef [Translated from the Spanish]

Florida Keys Declare Open Season on the Invasive Lionfish

\section{U.S. Coast Battles the Lionfish}

How to Conquer the Invasive Lionfish? Saute It

'Godzilla' Lionfish Threatening Cayman Paradise

Changing Seas, Alien Invaders

Answer for Invasive Species: Put It on a Plate and Eat It

Taming the Lionfish: Florida Fights Back Against Invasive Species

Scourge of the Lionfish, Part 3: The Newest Fish in the Kitchen

Lionfish Researcher Looks at Invasive Species. Dispels Fears, Tells of Lionfish as NonPoisonous Delicacy

Unwelcome Visitors

Lionfish Attacking Atlantic Ocean Like a Living Oil Spill

Even Sharks Are No Match for Invasive Lionfish

Lionfish Infestation in Atlantic Ocean a Growing Epidemic
Source and publication date

National Geographic News

01 June 2004

(Pickrell 2004)

The New York Times

08 September 2006

(Lambert 2006)

Turks and Caicos Weekly News

13 December 2008

(Bird 2008)

Fox News

14 August 2008

(Associated Press 2008)

Miami Herald

18 January 2008

Mundo Náutico

24 March 2009

St. Croix Source

23 August 2009

(Buchanan 2009)

Inter Press Service News Agency

02 December 2009

(Márquez 2009)

Radio Nederland Wereldomroep

06 January 2010

Sian Ka'an Tours.com

13 January 2010

The New York Times

22 November 2010

(Olsen 2010)

Wall Street Journal Online

15 August 2010

(WSJ Video 2010)

Washington Post

07 July 2010

(Eilperin 2010)

BBC News

07 May 2011

(Ecott 2011)

WPBT PBS

06 July 2011

(WPBT 2011)

The New York Times

09 July 2011

(Rosenthal 2011)

$\mathrm{CNN}$

26 April 2012

(Cousteau and Knight 2012)

The New York Times

10 October 2012

(Safina 2012)

The Anguillian

07 December 2012

CBS NEWS

21 February 2013

WLRN

18 April 2013

(Shogren 2013)

NBC News

12 July 2013

(Bryner 2013)

CNN

19 October 2013

(Linendoll 2013) 
Whereas the observed and potential negative impacts attributed to lionfish by ecologists and the media were considered alarming and used to incentivize removal programs, MPA stakeholders were more nuanced in their construction of lionfish impacts. In all MPAs some degree of lionfish research and/or monitoring had been conducted; however, site-specific ecological impact data were not yet available. The novelty of the issue and its inherent uncertainties were acknowledged by an MPA manager:

\section{It takes time for the ecological consequences of this type of invasion to actually be noticeable, whether it is through analysis of fisheries landings, or other studies that are done in an annual basis... Some of those may take a while for a signal to be observed, and after that... what's the correlation of that signal to the presence of lionfish?}

About $80 \%$ of respondents aligned themselves with the discourse that views lionfish as a threat. The majority likewise recognized high densities and voracity of lionfish as the main factors that could impact ecosystems and services local communities depend on. However, although agreement seemed to exist on the nature of the impacts of lionfish, stakeholders had divergent views regarding the extent of these impacts in specific sites, recognizing local differences. An MPA manager with a science background for instance questioned the generalizability of available impact data:

Lionfish has been demonized endlessly but the truth is that the science behind those statements is quite thin. There are very few studies that show to what extent lionfish influences the fish population on a reef. These are old studies...it is said that lionfish can reduce recruitment by $80 \%$ in five weeks - that's the classical speech. That's work done...in the Bahamas. What happens is, those are patchy reefs... Lionfish gets there and empties the reef... because there's little shelter due to low rugosity. So reef fish...cannot hide. Here... the reef is different, fish populations are totally different and their behavior is also different so I don't know in how far those results can be extrapolated [to our reefs].

A geographical difference in lionfish perceptions could be observed: about half of the respondents from the Eastern Caribbean MPAs considered lionfish a threat or problem, whereas more than $90 \%$ of respondents at the other MPAs did so. As mentioned in the Spread section, some respondents from Saba and St. Eustatius stated that lionfish were not observed in high numbers in their dive sites and therefore thought that lionfish were not impacting those areas.

\section{Lionfish control}

Storyline: Kill lionfish to protect Caribbean reefs Although the potential costs and benefits of lionfish removal programs have been debated (Frazer et al. 2012), there is consensus among scientists that local lionfish control is necessary to mitigate negative effects on the ecosystem and the economy. Lionfish removals are carried out manually by scuba divers or fishers using hand nets or small spearguns; hence, this activity is constrained by (wo)manpower and depth limits. Scientists have focused on seeking optimum removal rates through modeling and field studies, acknowledging that high levels of uncertainty due to data gaps make generalized predictions difficult. Whereas total eradication has been deemed unfeasible (Arias-González et al. 2011, Barbour et al. 2011) because of lionfish high reproduction, efficient larval dispersal, and depth constraints, a few studies provide data that substantiate claims that local control efforts yield positive results in terms of decreased lionfish biomass (Frazer et al. 2012, de León et al. 2013).

Lionfish removal events, also called safaris, derbies, or fishing tournaments, are organized in various locations, and bounties are provided as participation incentives. In addition, self-organized volunteers, who call themselves lionfish hunters, are active throughout the region. The media casts a positive light on lionfish removal events, with some headlines such as "Divers to Be Honored for Lionfish Kills" glorifying those who participate (Barlow 2012).

In some MPAs, debates emerged regarding the trade-offs of allowing/promoting spearfishing because of poaching concerns. A respondent from Curaçao noted: "You have some people on the island who are taking advantage of that law and they're spearing lobster, parrotfish, mullet...." Also, MPA managers are being called to relax regulations to allow removals in no-entry or no-take zones. These areas epitomize the nativist view of a pristine nature free of human interference, but also free of non-native species. Notwithstanding the expressed uncertainties, all MPA staff and government officials interviewed promoted lionfish removal efforts in their waters, albeit with some restrictions in terms of access because of zoning, gear use, and training requirements for licensed individuals, asserting that lionfish represent yet another risk factor to already-stressed reefs.

As stated in the Impact section, approximately $80 \%$ of respondents viewed lionfish as a threat and supported control measures. Within this coalition, a small group of respondents did not consider lionfish as a risk in their dive sites anymore because of a combination of active hunting and what they thought was natural control of lionfish populations. This argument was supported by personal observations of low lionfish numbers and the presence of large reef fish that were considered potential lionfish predators. For this group, nature is resilient but needs human intervention to restore health, their views best fitting with the rehabilitation metaphor.

Storyline: Don't kill lionfish; nature will balance itself About $20 \%$ of respondents, all professional divers, positioned themselves within a coalition that challenges the dominant "Kill lionfish" discourse. Different arguments were provided in support of this position. A small group within this coalition acknowledged the risk that the lionfish represents for native ecosystems but refused to kill them on moral and safety grounds. This group expressed animal rights and fear-based arguments as deterrents to engage in lionfish removals. Safety/liability concerns for both staff and clients included fear of being stung by lionfish, of injuries by spearing gear, and of being bitten or followed by large predators in search of speared lionfish:

In early November one of our guides got bitten by a shark. So unfortunately this has curtailed us from hunting them because we cannot risk that the sharks are associating divers with dead lionfish.

Also, some individuals considered killing lionfish against the philosophy of scuba diving, i.e., take only pictures, leave only 
Table 4. Stakeholders' discourses on Western Atlantic lionfish (Pterois sp.).

\begin{tabular}{|c|c|}
\hline Quotes from stakeholders associated to Caribbean MPAs & Metaphors of Nature \\
\hline $\begin{array}{l}\text { I've never heard or seen an invasive species that has done anything right for the system that they're introduced to... I } \\
\text { would tend to stay on the cautious side and would worry about it. }\end{array}$ & $\begin{array}{l}\text { Nativism: } \\
\text { Restoration }\end{array}$ \\
\hline \multicolumn{2}{|l|}{$\begin{array}{l}\text {..when [the dive guides] are gonna shoot it they explain [to the tourists] look, they're not supposed to be outside the } \\
\text { Pacific and Indian Ocean and [the tourists] go "OK." }\end{array}$} \\
\hline \multicolumn{2}{|l|}{$\begin{array}{l}\text { When it first came out ... they were scaring us to death "it's going to destroy your reefs, you're going to have } 50 \text { of } \\
\text { these on every dive." }\end{array}$} \\
\hline $\begin{array}{l}\text { So we had two management strategies, that is the direct control by physically eliminating the lionfish from the reef... } \\
\text { and the second...would be the introduction of two No Fishing Zones that we hope that maybe natural predators of } \\
\text { the lionfish could establish themselves and multiply - since the lionfish came in Curaçao in a damaged ecosystem by } \\
\text { overfishing. }\end{array}$ & $\begin{array}{l}\text { Restoration/ } \\
\text { Rehabilitation }\end{array}$ \\
\hline \multicolumn{2}{|l|}{$\begin{array}{l}\text { A lot of people think that what we're doing is very cruel. And I want to make it very clear as well that I don't enjoy... } \\
\text { killing. I do it because I think it's necessary to keep the other fish alive... }\end{array}$} \\
\hline $\begin{array}{l}\text { On the other hand...[lionfish can] potentially remove the impact or shift impact away from some species...it can } \\
\text { provide an added source of income for subsistence fishermen. }\end{array}$ & Reparation \\
\hline \multicolumn{2}{|l|}{$\begin{array}{l}\text { we need to get [lionfish]off the reef and I would probably just kill them to get them off the reef because it's } \\
\text { damaging our reefs but... giving it to the restaurants, they'll use it. }\end{array}$} \\
\hline $\begin{array}{l}\text { Whether you like it or not, [lionfish] are part of the ecosystem now. Like we are, we're invasive species. Especially me } \\
\text { [foreign dive operator]. }\end{array}$ & $\begin{array}{l}\text { Cosmopolitanism: } \\
\text { Recombination }\end{array}$ \\
\hline \multicolumn{2}{|l|}{ It's an invasive species but nature finds its balance, it finds its way. } \\
\hline $\begin{array}{l}\text { We don't hunt... we...feel that it's almost inevitable that these lionfish are going to take over, so I'm not sure how } \\
\text { much of a difference we're going to make. }\end{array}$ & \\
\hline
\end{tabular}

bubbles. Personal observations that native predators were starting to feed on lionfish were advanced to support the argument that human intervention is neither necessary nor sufficient to control lionfish populations:

Divers are diving one tenth of one percent of the reefs that are out there so there's no way they're going to have an impact [on lionfish populations]. Stop fishing those predators and let them have a balanced ecosystem.

Another small group was identified that opposed killing lionfish based on the explicit acceptance of this new species in the ecosystem, as long as lionfish numbers did not increase. These respondents also thought that native predators were keeping lionfish numbers in check, which accordingly renders human intervention unnecessary. Finally, a group expressed ambiguity toward the presence of lionfish and toward control efforts. Various individuals stated that initially they had been alarmed and engaged in lionfish removals, but subsequently their interest waned as they became accustomed to the presence of lionfish in their waters, implicitly accepting the novel species in their ecosystem. The position of these various groups fit with the cosmopolitanism view of recombination and hands-off management. Table 4 shows quotes illustrating stakeholders' discourses.

The argument for focusing attention on species that, through predation, could become a natural control mechanism of lionfish, e.g., sharks, large groupers, and snappers, resonates with the enemy-release hypothesis in ecology, which maintains that invasive species can thrive in novel ranges because their populations are not controlled by enemies. A debate has emerged around biocontrol of lionfish (Bruno et al. 2013, Mumby et al 2013), with one coalition stating that native predators are already consuming lionfish, a claim substantiated by a couple of reports from the scientific literature (Maljković et al. 2008, Pimiento et al. 2013) and numerous personal observations by divers and fishers. It is argued that populations of these large native reef fishes, which are overexploited in the Western Atlantic Ocean, should be restored and better protected from overfishing. Some individuals have attempted training potential predators to recognize lionfish as prey by feeding them dead or injured lionfish from their spear tips, a practice criticized as unsafe because it conditions large predators to associate divers with food. Also, sceptics state that although anecdotal evidence of native predators consuming lionfish may exist, their effect on lionfish populations is negligible. This coalition tends to recommend lionfish removal and consumption: man-as-ultimate-predator.

\section{Storyline: Eat lionfish}

Lionfish is edible and considered tasty. NOAA scientists launched a campaign in 2010 in line with the imagery of war: "Eat them to beat them." This campaign has been supported by scientific studies seeking to legitimize claims that the lionfish meets nutritional and safety requirements for human consumption, by REEF, and by celebrity chefs who promote lionfish as sustainable seafood (Morris et al. 2011). In the media this campaign was translated as a "do-good dish that helps balance ocean ecology" (Glader 2010). In 2010, NBC News aired a piece entitled "Do Your Civic Duty, Eat This Fish!” (Huus 2010). 
Respondents from Bonaire and Curaçao reported catching lionfish for their own consumption or sale to local restaurants. Lobster fishermen in the Florida Keys and Sian Ka'an were increasingly harvesting lionfish as by-catch in their traps and started to capitalize on the new species. Calls to further commercialize lionfish are being voiced by various stakeholder groups throughout the region. However, the discourse that advocates lionfish removal and consumption is been challenged by a coalition that questions safety for harvesters and consumers, and points to possible ecological and social side effects of an established lionfish fishery.

\section{Storyline: Don't eat lionfish}

Concerns about ciguatera poisoning through lionfish consumption were raised in various locations. ${ }^{1}$ On November 22 , 2011, the blog Green Antilles published a report titled "More data emerges about ciguatera toxin in lionfish" (Green Antilles; http:// www.greenantilles.com/2011/11/22/more-data-emerges-about-ciguateratoxin-in-lionfish/). This report and a press release by the NGO that manages the MPA on St. Maarten warned the population not to eat lionfish caught in Northeastern Caribbean waters, a known ciguatera region: "We tested several samples of lionfish meat and have found that unfortunately an uncomfortably high percentage showed the presence of ciguatoxin" (Nature Foundation 2011). Although no specific numbers were mentioned, the "data" in this press release initiated the to-eat-ornot-to-eat lionfish debate. A government official interviewed stated that "one of the biggest bottlenecks or barriers to lionfish control is the ciguatera issue."

Various respondents from the Eastern Caribbean challenged the validity of the data based on the quality of the test kit used, which was according to MPA staff members from Saba and St. Eustatius, respectively, a "very basic test" and "like a home-made kit...very sensitive...it can pick up other stuff as well.... And then the discussion was - was it really ciguatera or was it showing something else? There's really no answers." St. Maarten's MPA staff acknowledged the disputed quality of the test results:

We just had a positive or negative assay that we used so it's probably, you know, it can be that it was minuscule amounts, but as a conservation organization we were not comfortable promoting the fish as edible.

In contrast, a highly placed MPA staff member from St. Eustatius said they promoted lionfish consumption on the island:

We eat them here all the time, all the staff. I've eaten like 150 of them. We have not had any [ciguatera poisoning] incidents here, absolutely not.

The local population was not used to the new fish but according to the MPA representatives, many people had tasted lionfish dishes during an MPA outreach event. Of the three fishermen interviewed in St. Eustatius, one declared that he ate lionfish.

Tests conducted by the U.S. Food and Drug Administration (FDA) in the U.S. Virgin Islands added to the ciguatera debate (Robertson et al. 2013). The NBC News of June 2012 positioned the two U.S. federal agencies against each other: NOAA promotes lionfish consumption whereas the FDA “certainly do[es]n't promote any campaign like that since we have found levels above our guidance," according to lead author Robertson (Aleccia
2012). Referring to these data, which were still unpublished when NBC featured the story, a Florida stakeholder observed:

There was a report that was pretty damaging - a few months ago - about ciguatera poisoning and lionfish in high frequency.... I thought it was fairly irresponsible to release that. I believe where they did the research was in a high ciguatera poisoning area anyway, so the groupers and snappers probably have just as high a level as the lionfish.... So when you're trying to create a level of demand for [lionfish] consumption here in the States, where there's no high levels of ciguatera poisoning, they create a situation where the demand goes away because people read that " $40 \%$ of lionfish have ciguatera poisoning."

A few days after the NBC News story appeared, the Florida Keys News cited the FDA's spokesman seeking "to walk the agency back from Robertson's remarks," explaining that none of the lionfish tested in the study originated from the Keys (Silk 2012). The spokesman added nonetheless that "the Keys, along with several Caribbean islands, are known ciguatera zones." Staff from NOAA and the MPA responded by stressing that ciguatera is present in a variety of reef fishes, not only lionfish. The same week the Florida Sea Grant Program, a large research funding body, had issued a statement in response to the FDA data:

[D ] espite the fact that NOAA has an ongoing program to teach people how to catch and cook lionfish, given this new information, under no circumstances should any person affiliated with Florida Sea Grant advocate consuming these fish, regardless of the location from which they are taken. If someone tells you it is OK to eat lionfish, tell them that the latest FDA science indicates that there is a significant risk, and it is recommended that they DO NOT eat them. (Gill 2012)

The eat-them-to-beat-them coalition contends that "whatever small risk there is, is outweighed by the benefit [to the ecosystem]" and that "legitimate concerns about ciguatera should be balanced by responsible sourcing" (Aleccia 2012).

The FDA results were published in 2013 and, interestingly, the paper concludes that there are no data to suggest that lionfish outside of known ciguatera-endemic regions would be ciguatoxic (Robertson et al. 2013). However, the paper does not specify where these regions are, nor does it show where the toxic fish in their samples originated from within the U.S. Virgin Islands. Traditionally, ciguatera hotspots have been identified through local knowledge of fishers and residents. Respondents in this study indeed referred to some of these areas such as the Saba Bank, sometimes called the "poison bank" because of high ciguatera prevalence. Whereas the position of Saba's MPA staff and dive operators interviewed regarding lionfish consumption was ambivalent (hesitation because of "the tests they did at St. Maarten”), Saba fishermen have reported eating locally caught lionfish. Respondents from Bonaire, Curaçao, and Sian Ka'an did not seem to consider ciguatera a risk given the absence of this topic in their lionfish consumption narratives.

Envenomation through a sting from lionfish spines is another risk mentioned by individuals skeptical of the eat-lionfish discourse. Although its spines are venomous, lionfish flesh is not poisonous, a distinction that if not understood causes apprehension among 
potential consumers (Anguillian, 2012). Venomous organisms deliver or inject a toxin directly, usually from an internal gland. Poisonous organisms typically secrete a toxin externally and may be harmful when touched or ingested. Lionfish is thus venomous but not poisonous, and the highest risk of being stung hence accrues to those who harvest or process the fish. The eat-themto-beat-them coalition emphasizes that once the spines are removed (or cooked), eating the fish is safe. Also, this coalition stresses that no fatalities have been reported from envenomations. Respondents from Sian Ka'an report a shift from the initial stages of the invasion, when people were scared to get stung, to a situation where eating lionfish has become widely accepted in neighboring Cozumel, which is profiling itself as a culinary touristic destination, with lionfish as key attraction (Cruz 2013).

Promotion of invasive species consumption to control populations is not new, but the trend has intensified in recent years and has been picked up by the media, using the term "invasivores" to refer to "those who eat non-native (invasive) species" (Gorman 2010). The Mexican agency CONANP released a documentary entitled Lionfish: From Threat to Opportunity that showcases a fishing cooperative harvesting lionfish in Sian Ka'an both for the local and international seafood markets (CONANP 2012). Media headlines in various Caribbean sites provide a similar message: "Scourge of the Lionfish, Part 3: The Newest Fish in the Kitchen" (Safina 2012a) and "Lionfish: Profitable Danger" (Avila 2013). This stance fits with the reparation metaphor.

Caveats about mitigation efforts that rest on consumption of the invasive species are recognized. The New York Times warned that marketing invasive species may make them so popular that people "raise or release the fish where they did not already exist... potentially exacerbating the problem" (Rosenthal 2011). Respondents from Curaçao and Bonaire contend that some individuals purposefully leave the small lionfish in the reef to grow larger:

It started out pretty good, now that there's a market and people can make money out of it, people are getting greedy.... For example, they would leave the small fish behind and would go back a couple of weeks later so that [the lionfish is] big enough so that they can make money.

Among ecologists, the dominant discourse is that lionfish consumption is a promising control strategy. Only one article was found where a marine biologist questioned the effectiveness of lionfish commercialization, in particular if regulatory aspects are not addressed simultaneously. The author's arguments are in line with those of The New York Times. Further, he criticizes the way lionfish commercialization has evolved in Mexico, which he calls a disorganized market with "malicious incentives to either monopolize markets or even prevent benevolent people to make a living of the new market" (Aguilar-Perera 2012:318). For some respondents, harvesting lionfish manually for food is not worth the trouble because of the effort, costs, and risk involved in capturing and processing lionfish, and because the flesh yield is limited. Within the eat-lionfish coalition, development of a specialized lionfish trap is advocated, but the counterarguments are that, besides being expensive to develop, traps are not as species specific (hence sustainable) as manual removals. A spearlionfish versus trap-lionfish debate has emerged on the grounds of cost-effectiveness and sustainability of removal methods, but thus far no data had been brought forward to substantiate claims.

\section{DISCUSSION}

\section{Scientific and media construction of the lionfish invasion}

The use among ecologists of subjective and normative terms to refer to the lionfish and its management is similar to how other introduced species considered harmful are conceptualized and portrayed in scientific studies, a practice that has been constantly debated (Brown and Sax 2004, Colautti and MacIsaac 2004, Cassey et al. 2005, Colautti and Richardson 2009, Young and Larson 2011). The shrub Tamarix, for instance, considered invasive in the western United Sates, has been referred to as "evil" by scientists who argue for its removal (Stromberg et al. 2009). Expressions of subjectivity and advocacy by scientists are disapproved of by some scholars, who argue that these expressions undermine scientific credibility, while being defended by others as a logical result of the values that guide people toward a career in ecology and conservation biology (Barry and Oelschlaeger 1996, Brown and Sax 2004, Cassey et al. 2005, Larson 2007a, Colautti and Richardson 2009).

These tensions are illustrated by a survey among 422 invasion biologists, which showed that $94 \%$ agreed with the statement: "The role of scientists in studying invasive species should be to gather, interpret, and communicate information as accurately and objectively as possible" (Young and Larson 2011:895). However, responses were split regarding the statement "Any characterization that nonindigenous species are good or bad is a value judgment, not science" (49\% agreed, 40\% disagreed; Young and Larson 2011:895), which suggests that some scientists may not recognize the underlying values they communicate along with their findings. The scientific discourse on Atlantic lionfish is clear in its characterization of this species as a threat, hence bad for native ecosystems, based on measured and assumed impacts (but see Elise et al. 2015), and this characterization reflects the values and beliefs encapsulated by nativism.

News reports' uptake of the scientific message on lionfish echoes other studies on the conceptualization and framing by the media of invasive species as enemies (Larson 2008). Media reports consistently quoted lionfish scientists and experts, a common journalistic practice to ensure empirical validity and enhance media credibility (Pan and Kosicki 1993). Also, various news items built their story around recently released scientific studies, including data and interviews with the authors. This study found that scientists' language use when interviewed by the media was more emotive than that in their academic reports. Wong (2002) shows that invasion scientists in the United States admit communicating with other scientists through journals differently than they communicate with the public through journalists. Despite their recognition that terms such as invasive, alien, or exotic are loaded, scientists use them to capture public attention (Wong 2002).

A study on the social construction of purple loosestrife, an invasive plant in North American wetlands, found that the media attributed more negative impacts to the plant than scientists did (Lavoie 2010). In contrast, media and scientific reports portrayed a comparable image of lionfish, although the media's language use was more inflated. Militaristic metaphors, for instance, were more widespread and explicit in media reports than in scientific writings on lionfish. Social scientists commonly criticize the practice of appealing to the fear factor through use of war and catastrophe metaphors related to invasive species. As such, a sense 
of urgency and need for action are created, but these can result in paralysis or counteraction instead of the hoped-for action (Gobster 2005, Nerlich and James 2009).

During the initial stages of the lionfish invasion, warnings by scientists, management agencies, and the media instilled fear among marine resource users. By using not only catastrophe frames, however, but also solution-oriented frames such as lionfish removal and consumption, the dominant discourse on lionfish has been successful in its call for action, as demonstrated by the findings of this study and by multiple reports of divers and fishers engaged in lionfish control throughout the region (Morris 2012, Festa 2014), as well as the August 2014 import ban of live lionfish into the state of Florida (Talbot 2014). Solution frames are consistent with the rehabilitation and reparation metaphors, with the latter's emphasis on the function of lionfish not only as a new commodity but also as a green seafood choice, contributing to a win-win rhetoric.

\section{Stakeholder constructions of the lionfish invasion}

Although the majority of the respondents perceived lionfish as a threat and engaged in lionfish control, about $20 \%$ of respondents diverged from this dominant discourse, their views best fitting with the recombination metaphor. On the Eastern Caribbean islands, divergent positions had proportionally larger implications for lionfish management than in the other MPAs studied because of the smaller number of stakeholders available to participate in lionfish removal activities. For instance, whereas only two dive operators exist on St. Eustatius and three on Saba, managers and/or staff from one dive shop at each site refused to engage in lionfish removals. From the perspective of MPA goals, this position is in conflict with the intended aims to control lionfish at the local scale.

Among stakeholders within the "Kill lionfish" coalition, lionfish perceptions seemed to be influenced by the lionfish numbers that respondents personally observed underwater, in particular when there was a rapid increase in numbers, coupled to factual understanding of the species' voraciousness. Among opponents of removals, willingness to engage in this activity was expressed by certain individuals only if lionfish numbers would increase in their area. In a survey among spearfishers in the Gulf of Mexico, $75 \%$ of respondents perceived lionfish as harmful or very harmful for marine ecosystems (Scyphers et al. 2014). Scyphers et al. showed that perceived harmfulness was correlated to spearfishers' reported encounters with lionfish during their dives and that these perceptions were a powerful predictor of individuals' willingness to participate in control initiatives. The findings of the present study, although not based on a quantitative approach, are consistent with the survey results.

The eat-them-to-beat-them discourse, based on the view that fishermen are capable of exploiting fish almost to extinction (Moore 2012), is challenged by a coalition that questions the safety and effectiveness of the practices promoted by this campaign. Potential side effects could backfire because incorporating lionfish into local cuisines could undermine desired ecological outcomes. Indeed, a nascent discourse on lionfish as fulfilling the role of overexploited native species, primarily expressed in economic terms but possibly in the cultural sense as well (Nuñez et al. 2012, Festa 2014), is shifting lionfish impacts from negative to positive among various stakeholder groups.
Competing discourses regarding the consumption of lionfish emerged because of ciguatera risk perceptions. At a meeting in November 2013, the kill-and-eat-lionfish coalition argued that lionfish should be treated like other reef fish with regards to ciguatera by the seafood industry and seafood health regulators (Bogdanoff et al. 2014). Renewed research interest on the topic is generating new data and feeding the debate, such as the recent finding that false-positive tests for ciguatera may be occurring because of the similarity between ciguatoxins and lionfish venom (Wilcox and Hixon 2014).

The balance of nature was a recurrent trope in many stakeholders' discourses. Whereas in ecology, perceptions of ecosystems have shifted from static entities in equilibrium to dynamic, complex, and unpredictable systems (Wu and Loucks 1995), the balance metaphor persists among many ecologists (Cuddington 2001) and in lay people's beliefs about nature (Buijs 2009). The role of predators, including humans, in maintaining lionfish populations within some balance threshold is a key discursive element herein and a source of debate. Regarding biocontrol, four scientific studies have addressed the question of whether natural predators are preying on healthy lionfish and/or affecting their populations in Caribbean reefs, with mixed results (Mumby et al. 2011, Hackerott et al. 2013, Diller et al. 2014, Valdivia et al. 2014). Last year, Saba fishermen reported frequent observations of lionfish in snappers' stomachs trapped at 100-m depth, a finding that a local manager seeks to confirm through a scientific approach (Spalburg 2014). Anecdotal evidence of lionfish being preyed upon have become "scientific" data when these observations were verified and reported in academic journals (Maljković et al. 2008, Pimiento et al. 2013).

Lionfish control by humans is controversial for various reasons, including doubts of the effectiveness of spearfishing (Côté et al. 2014) and concerns that some individuals could abuse amendments made to spearfishing gear use and no-take zone regulations in various MPAs to target other species. On Bonaire and Curaçao, for instance, spearfishing is illegal and special permits are issued for lionfish capture only (de León et al. 2013), but enforcement is difficult. Moreover, moral considerations play a role among a minority who opposes killing lionfish. Animal rights discourses have dominated the debate in other cases of invasive species management, particularly when species are considered charismatic. For example, plans to eradicate the American grey squirrel in Italy because of concerns about its competitive exclusion of the native red squirrel were halted because of public opposition (Genovesi and Bertolino 2001).

Studies have shown that public attitudes to species management are influenced by how target species are perceived (Bremner and Park 2007). For instance, perceptions differ between "hated invasives" such as rats and "attractive invasives" as birds and certain plant species (Bremner and Park 2007). Also, people tend to have negative perceptions of predators (Kellert 1985). In the case of lionfish, many stakeholders reported mixed feelings toward this species. A New York Times science writer reflects: "It's a sad commentary about how we're changing the world that killing and eating one of the world's most beautiful fish — as long as they're from the Caribbean or Atlantic Ocean - actually helps" (Safina, 2012b). 


\section{CONCLUSIONS}

The lionfish invasion of the Western Atlantic Ocean has driven two significant shifts in scientific discourses on marine fish invasions and their vector. Initially considered rare and low risk, now marine fish invasions are believed to be potentially common and high risk. Secondly, the aquarium industry, which was previously not recognized as an important introduction vector, is now subject to scrutiny and public pressure.

Current scientific understanding of Atlantic lionfish is characterized by a discourse that conceptualizes lionfish as a threat and that advocates lionfish removal programs to mitigate its negative impacts on vulnerable ecosystems and human communities. The media have taken over and amplified this message, adding some balance on the invasivore issue, while MPA stakeholders incorporate their own experiences into their lionfish accounts, resulting in some divergence from scientific claims. In building their arguments about lionfish, actors use data and information that substantiate their views, and do so using particular metaphorical lenses. Stakeholders challenge the validity of scientific data by drawing from their own experience, as in the ciguatera risk or the biocontrol debates. In some cases, systematic observations by stakeholders to test their own hypotheses in pseudoexperiments arguably approach scientific methods, e.g., eating "150 lionfish and getting no ciguatera."

Discourses may converge in the future on the biocontrol debate. Despite numerous incidents of large reef fish and lobsters preying on lionfish reported by fishers and divers, this "citizen data" or local knowledge is not yet considered scientific and hence is put aside in the current discourse. If data accumulate on direct and indirect observations of lionfish being preyed upon to levels that could control their numbers, the enemy-release hypothesis could be challenged at least in particular sites.

This study illustrates that biological invasions should be understood as a social-ecological phenomenon. Scientific data and metaphors, amplified by the media, proved instrumental to gain initial understanding of the new lionfish phenomenon and to legitimize claims. In time, however, local knowledge and societal values have intermingled with scientific data, sometimes challenging scientific discourses, and always contributing to a richer understanding of the invasion in all its facets.

Responses to this article can be read online at: http://www.ecologyandsociety.org/issues/responses. php/7726

\section{Acknowledgments:}

I thank professor Dr. Arthur Mol, Dr. Hilde Tobi, and Susan Boonman-Berson for their valuable contribution to earlier versions of the manuscript, all the informants for accepting to participate in this study, and the Jo Kolk Studiefonds for financial support during fieldwork.

\section{LITERATURE CITED}

Aguilar-Perera, A. 2012. Eating lionfish: an effective solution to control its invasion? Pages 315-320 in Proceedings of the 65th Gulf and Caribbean Fisheries Institute. Santa Marta, Colombia.

Albins, M. A., and M. A. Hixon. 2008. Invasive Indo-Pacific lionfish Pterois volitans reduce recruitment of Atlantic coral-reef fishes. Marine Ecology Progress Series 367:233-238. http://dx.doi. org/10.3354/meps07620

Aleccia, J. 2012. Eat lionfish? Sure, but beware of the nasty toxins. NBC News, 27 June. [online] URL: http://vitals.nbcnews.com/ nnews/2012/06/27/12423879-eat-lionfish-sure-but-beware-of-thenasty-toxins

Ali, F. 2011. Understanding the lionfish invasion in Bonaire to develop the best strategy for Trinidad and Tobago. Pages 57-64 in Proceedings of the 64th Gulf and Caribbean Fisheries Institute. Puerto Morelos, Mexico.

Anguillian. 2012. Lionfish researcher looks at invasive species. Dispels fears, tells of lionfish as non-poisonous delicacy. Anguillean, 7 December. [online] URL: http://theanguillian. com/2012/12/lionfish-researcher-looks-at-invasive-species-dispelsfears-tells-of-lionfish-as-non-poisonous-delicacy/

Arias-González, J. E., C. González-Gándara, J. L. Cabrera, and V. Christensen. 2011. Predicted impact of the invasive lionfish Pterois volitans on the food web of a Caribbean coral reef. Environmental Research 111(7):917-925. http://dx.doi.org/10.1016/ j.envres.2011.07.008

Arts, K., A. Fischer, and R. van der Wal. 2012. Common stories of reintroduction: a discourse analysis of documents supporting animal reintroductions to Scotland. Land Use Policy 29 (4):911-920. http://dx.doi.org/10.1016/j.landusepol.2012.01.009

Associated Press. 2008. Poisonous lionfish invade Caribbean, head up Eastern Seaboard. Fox News, 14 August. [online] URL: http://www.foxnews.com/story/2008/08/14/poisonous-lionfish-invadecaribbean-head-up-eastern-seaboard.html

Avila, E. 2013. Pez León, peligrosidad redituable. El Quintanarroense, 8 April. [online] URL: http://issuu.com/ elquintanarroense/docs/edicion digital 08-04-13/1

Barbour, A. B., M. S. Allen, T. K. Frazer, and K. D. Sherman. 2011. Evaluating the potential efficacy of invasive lionfish (Pterois volitans) removals. PLoS One 6(5):e19666. http://dx.doi. org/10.1371/journal.pone.0019666

Barlow, K. C. 2012. Divers to be honored for lionfish kills. Northwest Florida Daily News, 25 October. [online] URL: http:// www.nwfdailynews.com/article/20121025/NEWS/310259974/0/

Barry, D., and M. Oelschlaeger. 1996. A science for survival: values and conservation biology. Conservation Biology 10 (3):905-911. http://dx.doi.org/10.1046/j.1523-1739.1996.10030904-2. $\underline{\mathrm{X}}$

Betancur, R. R., A. Hines, P. Acero, G. Ortí, A. E. Wilbur, and D. W. Freshwater. 2011. Reconstructing the lionfish invasion: insights into Greater Caribbean biogeography. Journal of 
Biogeography 38(7):1281-1293. http://dx.doi.org/10.1111/ j.1365-2699.2011.02496.x

Bird, R. 2008. Lionfish: born in the wrong sea. Turks and Caicos Weekly News, 13 December. [online] URL: http://tcweeklynews. com/lionfish-born-in-the-wrong-sea-p1027-1.htm

Bogdanoff, A. K., J. L. Akins, J. A. Morris, Jr., and 2013 GCFI Lionfish Workgroup. 2014. Invasive lionfish in the marketplace: challenges and opportunities. Pages 140-147 in Proceedings of the 66th Gulf and Caribbean Fisheries Institute. Corpus Christi, Texas, USA.

Boonman-Berson, S., E. Turnhout, and J. van Tatenhove. 2014. Invasive species: the categorization of wildlife in science, policy, and wildlife management. Land Use Policy 38:204-212. http://dx. doi.org/10.1016/j.landusepol.2013.11.002

Bremner, A., and K. Park. 2007. Public attitudes to the management of invasive non-native species in Scotland. Biological Conservation 139(3):306-314. http://dx.doi.org/10.1016/ j.biocon.2007.07.005

Brown, J. H., and D. F. Sax. 2004. An essay on some topics concerning invasive species. Austral Ecology 29(5):530-536. http:// dx.doi.org/10.1111/j.1442-9993.2004.01340.x

Bruno, J. F., A. Valdivia, S. Hackerott, C. E. Cox, S. Green, I. Côté, L. Akins, C. Layman, and W. Precht. 2013. Testing the grouper biocontrol hypothesis: a response to Mumby et al. 2013. PeerJ PrePrints 1:e139v1. https://dx.doi.org/10.7287/peerj. preprints. $139 \mathrm{v} 1$

Bryce, R., M. K. Oliver, L. Davies, H. Gray, J. Urquhart, and X. Lambin. 2011. Turning back the tide of American mink invasion at an unprecedented scale through community participation and adaptive management. Biological Conservation 144(1):575-583. http://dx.doi.org/10.1016/j.biocon.2010.10.013

Bryman, A. 2012. Social research methods. Oxford University Press, Oxford, UK.

Bryner, J. 2013. Even sharks are no match for invasive lionfish. NBC News, 12 July. [online] URL: http://www.nbcnews.com/ science/even-sharks-are-no-match-invasive-lionfish-6C10621635

Buchanan, D. 2009. Influx of lionfish a threat to native marine life, experts say. St. Croix Source, 23 August. [online] URL: http:// stcroixsource.com/content/news/local-news/2009/08/23/influx-lionfishthreat-native-marine-life-experts-say

Buijs, A. E. 2009. Lay people's images of nature: comprehensive frameworks of values, beliefs, and value orientations. Society and Natural Resources 22(5):417-432. http://dx.doi.org/10.1080/089$\underline{41920801901335}$

Callicott, J. B., L. B. Crowder, and K. Mumford. 1999. Current normative concepts in conservation. Conservation Biology 13 (1):22-35. http://dx.doi.org/10.1046/j.1523-1739.1999.97333.x

Carlton, J. T., and J. B. Geller. 1993. Ecological roulette: the global transport of nonindigenous marine organisms. Chemical Physics Letters 179:53.

Cassey, P., T. M. Blackburn, R. P. Duncan, and S. L. Chown. 2005. Concerning invasive species: reply to Brown and Sax. Austral Ecology 30(4):475-480. http://dx.doi.org/10.1111/ j.1442-9993.2005.01505.x
CBS News. 2013. Lionfish: Invasive species devastating reefs, experts say. CBS News, 21 February. [online] URL: http://www. cbsnews.com/news/lionfish-invasive-species-devastating-reefs-expertsays/

Chew, M. K., and M. D. Laubichler. 2003. Natural enemiesmetaphor or misconception? Science 301(5629):52-53. http://dx. doi.org/10.1126/science.1085274

Clavero, M., and E. García-Berthou. 2005. Invasive species are a leading cause of animal extinctions. Trends in Ecology \& Evolution 20(3):110. http://dx.doi.org/10.1016/j.tree.2005.01.003

Claydon, J. A. B., M. C. Calosso, and S. B. Traiger. 2012. Progression of invasive lionfish in seagrass, mangrove and reef habitats. Marine Ecology Progress Series 448:119-129. http://dx. doi.org/10.3354/meps09534

Cocking, S. 2013. Florida starts planning to attack invasive lionfish. Miami Herald, 26 October.

Colautti, R. I., and H. J. MacIsaac. 2004. A neutral terminology to define 'invasive' species. Diversity and Distributions 10 (2):135-141. http://dx.doi.org/10.1111/j.1366-9516.2004.00061.x

Colautti, R. I., and D. M. Richardson. 2009. Subjectivity and flexibility in invasion terminology: too much of a good thing? Biological Invasions 11(6):1225-1229. http://dx.doi.org/10.1007/ s10530-008-9333-Z

Comisión Nacional de Áreas Naturales Protegidas (CONANP). 2012. La Invasión del pez león. CONAMP TV and Sociedad Cooperativa de Producción Pesquera Cozumel, 26 October. [online] URL: https://www.youtube.com/watch?v=bYKHubHV16Y

Côté, I. M., L. Akins, E. Underwood, J. Curtis-Quick, and S. J. Green. 2014. Setting the record straight on invasive lionfish control: culling works. PeerJ PrePrints 2:e398v1 https://dx.doi. org/10.7287/peerj.preprints.398v1

Côté, I. M., S. J. Green, and M. A. Hixon. 2013. Predatory fish invaders: insights from Indo-Pacific lionfish in the western Atlantic and Caribbean. Biological Conservation 164:50-61. http://dx.doi.org/10.1016/j.biocon.2013.04.014

Courtenay, W. R. J. 1995. Marine fish introductions in southeastern Florida. American Fisheries Society Introduced Fish Section Newsletter 14(1):2-3.

Cousteau, P., and M. Knight. 2012. Taming the lionfish: Florida fights back against invasive species. CNN, 26 April. [online] URL: http://www.cnn.com/2012/04/24/us/lionfish/index.html

Crall, A. W., G. J. Newman, C. S. Jarnevich, T. J. Stohlgren, D. M. Waller, and J. Graham. 2010. Improving and integrating data on invasive species collected by citizen scientists. Biological Invasions 12(10):3419-3428. http://dx.doi.org/10.1007/s10530-010-9740-9

Cruz, R. 2013. Tiene Cozumel “ceviche de pez león” más grande del mundo. Público.mx, 20 September. [online] URL: http://www. publico.mx/nota/51986/

Cuddington, K. 2001. The "balance of nature" metaphor and equilibrium in population ecology. Biology and Philosophy 16 (4):463-479. http://dx.doi.org/10.1023/A:1011910014900 
Daehler, C. C. 2001. Two ways to be an invader, but one is more suitable for ecology. Bulletin of the Ecological Society of America 101-102.

Davis, M., and K. Thompson. 2000. Eight ways to be a colonizer; two ways to be an invader. Bulletin of the Ecological Society of America 81(3):226-230.

Davis, M. A., M. K. Chew, R. J. Hobbs, A. E. Lugo, J. J. Ewel, G. J. Vermeij, J. H. Brown, M. L. Rosenzweig, M. R. Gardener, S. P. Carroll, et al. 2011. Don't judge species on their origins. Nature 474(7350):153-154. http://dx.doi.org/10.1038/474153a

de León, R., K. Vane, P. Bertuol, V. C. Chamberland, F. Simal, E. Imms, and M. J. A. Vermeij. 2013. Effectiveness of lionfish removal efforts in the southern Caribbean. Endangered Species Research 22(2):175-182. http://dx.doi.org/10.3354/esr00542

Dickie, I. A., B. M. Bennett, L. E. Burrows, M. A. Nuñez, D. A. Peltzer, A. Porté, D. M. Richardson, M. Rejmánek, P. W. Rundel, and B. W. van Wilgen. 2014. Conflicting values: ecosystem services and invasive tree management. Biological Invasions 16 (3):705-719. http://dx.doi.org/10.1007/s10530-013-0609-6

Diller, J. L., T. K. Frazer, and C. A. Jacoby. 2014. Coping with the lionfish invasion: evidence that naïve, native predators can learn to help. Journal of Experimental Marine Biology and Ecology 455:45-49. http://dx.doi.org/10.1016/j.jembe.2014.02.014

Donlan, C. J., and P. S. Martin. 2004. Role of ecological history in invasive species management and conservation. Conservation Biology 18(1):267-269. http://dx. doi.org/10.1111/j.1523-1739.2004.00101. $\underline{x}$

Ecott, T. 2011. 'Godzilla' lionfish threatening Cayman paradise. BBC News, 7 May. [online] URL: http://news.bbc.co.uk/2/hi/ programmes/from our own correspondent/9477235.stm

Eilperin, J. 2010. How to conquer the invasive lionfish? Saute it. Washington Post, 07 July. [online] URL: http://www. washingtonpost.com/wp-dyn/content/article/2010/07/06/ AR2010070601003.html

Elise, S., I. Urbina-Barreto, H. Boadas-Gil, M. Galindo-Vivas, and M. Kulbicki. 2015. No detectable effect of lionfish (Pterois volitans and $P$. miles) invasion on a healthy reef fish assemblage in Archipelago Los Roques National Park, Venezuela. Marine Biology 162(2):319-330. http://dx.doi.org/10.1007/s00227-014-2571y

Estévez, R. A., C. B. Anderson, J. C. Pizarro, and M. A. Burgman. 2015. Clarifying values, risk perceptions, and attitudes to resolve or avoid social conflicts in invasive species management. Conservation Biology 29(1):19-30. http://dx.doi.org/10.1111/ cobi.12359

Evans, J. M., A. C. Wilkie, and J. Burkhardt. 2008. Adaptive management of non-native species: moving beyond the "eitheror" through experimental pluralism. Journal of Agricultural and Environmental Ethics 21(6):521-539. http://dx.doi.org/10.1007/ $\underline{\text { s10806-008-9118-5 }}$

Falk-Petersen, J., T. Bøhn, and O. T. Sandlund. 2006. On the numerous concepts in invasion biology. Biological Invasions 8 (6):1409-1424. http://dx.doi.org/10.1007/s10530-005-0710-6
Fereday, J., and E. Muir-Cochrane. 2008. Demonstrating rigor using thematic analysis: a hybrid approach of inductive and deductive coding and theme development. International Journal of Qualitative Methods 5(1):80-89.

Festa, J. 2014. Caribbean crisis: how eating lionfish can help save the planet. Epicure \& Culture, 30 July. [online] URL: http:// epicureandculture.com/lionfish/

Ford-Thompson, A. E., C. Snell, G. Saunders, and P. C. White. 2012. Stakeholder participation in management of invasive vertebrates. Conservation Biology 26(2):345-356. http://dx.doi. org/10.1111/j.1523-1739.2011.01819.x

Foster, J., and L. A. Sandberg. 2004. Friends or foe? Invasive species and public green space in Toronto. Geographical Review 94(2):178-198. http://dx.doi.org/10.1111/j.1931-0846.2004.tb00166. $\underline{x}$

Frazer, T. K., C. A. Jacoby, M. A. Edwards, S. C. Barry, and C. M. Manfrino. 2012. Coping with the lionfish invasion: can targeted removals yield beneficial effects? Reviews in Fisheries Science 20(4):185-191. http://dx.doi.org/10.1080/10641262.2012.700655

Freshwater, D. W., A. Hines, S. Parham, A. Wilbur, M. Sabaoun, J. Woodhead, L. Akins, B. Purdy, P. E. Whitfield, and C. B. Paris. 2009. Mitochondrial control region sequence analyses indicate dispersal from the U.S. East Coast as the source of the invasive Indo-Pacific lionfish Pterois volitans in the Bahamas. Marine Biology 156(6):1213-1221. http://dx.doi.org/10.1007/s00227-009-1163-8

García-Llorente, M., B. Martín-López, J. A. González, P. Alcorlo, and C. Montes. 2008. Social perceptions of the impacts and benefits of invasive alien species: implications for management. Biological Conservation 141(12):2969-2983. http://dx.doi.org/10.1016/ j.biocon.2008.09.003

Genovesi, P., and S. Bertolino. 2001. Human dimension aspects in invasive alien species issues: the case of the failure of the grey squirrel eradication project in Italy. Pages 113-119 in J. A. McNeely, editor. The great reshuffling: human dimensions of invasive alien species. International Union for Conservation of Natural and Natural Resources, Gland, Switzerland, and Cambridge, UK.

Gill, E. 2012. Florida Sea Grant says not to eat lionfish. TCPalm, 2 July. [online] URL: http://www.tcpalm.com/news/2012/jul/02/ florida-sea-grant-says-not-to-eat-lionfish-23815/

Glader, P. 2010. The lionfish creates an uproar, bringing out the hunters. Voracious intruders stalked with spears; doing your part by eating them. Wall Street Journal, 15 November. [online] URL: http://www.wsj.com/articles/SB10001424052748704658204575610721532882174

Gobster, P. H. 2005. Invasive species as ecological threat: is restoration an alternative to fear-based resource management? Ecological Restoration 23(4):261-270. http://dx.doi.org/10.3368/ er.23.4.261

Golani, D., and O. Sonin. 1992. New records of the Red Sea fishes, Pterois miles (Scorpaenidae) and Pteragogus pelycus (Labridae) from the eastern Mediterranean Sea. Ichthyological Research 39 (2):167-169. 
Gómez, Y. 2010. Status of the lionfish (Pteroris sp.) in the Sian Ka'an and the Sian Ka'an reefs biosphere reserves. Global Invasive Species database. Invasive Species Specialist Group, University of Auckland, Aukland, New Zealand.

Gómez Lozano, R., L. Anderson, J. L. Akins, D. S. A. Buddo, G. García-Moliner, F. Gourdin, M. Laurent, C. Lilyestrom, J. A. Morris, N. Ramnanan, and R. Torres. 2013. Regional strategy for the control of invasive lionfish in the wider Caribbean. International Coral Reef Initiative, $31 \mathrm{pp}$.

Gorman, J. 2010. A diet for an invaded planet: invasive species. New York Times, 31 December. [online] URL: http://www. nytimes.com/2011/01/02/weekinreview/02gorman.html

Graham, N. A. J., J. E. Cinner, A. V. Norström, and M. Nyström. 2014. Coral reefs as novel ecosystems: embracing new futures. Current Opinion in Environmental Sustainability 7:9-14. http://dx. doi.org/10.1016/j.cosust.2013.11.023

Graham, N. A. J., and C. C. Hicks. 2015. Adaptive management for novel ecosystems. Pages 123-146 in C. R. Allen and A. S. Garmestani, editors. Adaptive management of social-ecological systems. Springer, Dordrecht, The Netherlands. http://dx.doi. org/10.1007/978-94-017-9682-8 8

Green, S., and I. Côté. 2009. Record densities of Indo-Pacific lionfish on Bahamian coral reefs. Coral Reefs 28(1):107-107. http://dx.doi.org/10.1007/s00338-008-0446-8

Green, S. J., J. L. Akins, A. Maljković, and I. M. Côté. 2012. Invasive lionfish drive Atlantic coral reef fish declines. PLoS One 7(3):e32596. http://dx.doi.org/10.1371/journal.pone.0032596

Gulf and Caribbean Fisheries Institute (GCFI). 2014. Book of abstracts. Proceedings of the 67th GCFI (Christ Church, Barbados). GCFI, Fort Pierce, Florida, USA.

Gurevitch, J., and D. K. Padilla. 2004. Are invasive species a major cause of extinctions? Trends in Ecology \& Evolution 19(9):470-474. http://dx.doi.org/10.1016/j.tree.2004.07.005

Hackerott, S., A. Valdivia, S. J. Green, I. M. Côté, C. E. Cox, L. Akins, C. A. Layman, W. F. Precht, and J. F. Bruno. 2013. Native predators do not influence invasion success of Pacific lionfish on Caribbean reefs. PLoS One 8(7):e68259. http://dx.doi. org/10.1371/journal.pone.0068259

Haider, S., and K. Jax. 2007. The application of environmental ethics in biological conservation: a case study from the southernmost tip of the Americas. Biodiversity and Conservation 16(9):2559-2573. http://dx.doi.org/10.1007/s10531-006-9088-8

Hajer, M. A. 1997. The politics of environmental discourse: ecologicalmodernization and the policy process. Oxford University Press, Oxford, UK. http://dx.doi.org/10.1093/019829333x.001.0001

Hall, M. 2003. Editorial: the native, naturalized and exoticplants and animals in human history. Landscape Research 28 (1):5-9. http://dx.doi.org/10.1080/01426390306534

Hamner, R., D. W. Freshwater, and P. E. Whitfield. 2007. Mitochondrial cytochrome b analysis reveals two invasive lionfish species with strong founder effects in the western Atlantic. Journal of Fish Biology 71:214-222. http://dx.doi.org/10.1111/ j.1095-8649.2007.01575.x
Hare, J. A., and P. E. Whitfield. 2003. An integrated assessment of the introduction of Lionfish (Pterois volitans/miles complex) to the Western Atlantic Ocean. National Oceanic and Atmospheric Administration (NOAA) Technical Memorandum NOS NCCOS, 2. NOAA/National Ocean Service/National Centers for Coastal Ocean Science/Center for Coastal Fisheries and Habitat Research, Beaufort, North Carolina, USA.

Heger, T., W.-C. Saul, and L. Trepl. 2013. What biological invasions 'are' is a matter of perspective. Journal for Nature Conservation 21(2):93-96. http://dx.doi.org/10.1016/j.jnc.2012.11.002

Huus, K. 2010. Do your civic duty, eat this fish! NBC News, 10 August. [online] URL: http://www.nbenews.com/id/38632799/ns/ us news-environment/t/do-your-civic-duty-eat-fish/\#.Va--jrdb7GW

Irwin, A. 1995. Citizen science: a study of people, expertise, and sustainable development. Routledge, Abington, UK.

Jud, Z. R., P. K. Nichols, and C. A. Layman. 2015. Broad salinity tolerance in the invasive lionfish Pterois spp. may facilitate estuarine colonization. Environmental Biology of Fishes 98 (1):135-143. http://dx.doi.org/0.1007/s10641-014-0242-y

Kellert, S. R. 1985. Public perceptions of predators, particularly the wolf and coyote. Biological Conservation 31(2):167-189. http:// dx.doi.org/10.1016/0006-3207(85)90047-3

Keulartz, J., and C. van der Weele. 2008. Framing and reframing in invasion biology. Configurations 16(1):93-115. http://dx.doi. org/10.1353/con.0.0043

Kimball, M. E., J. M. Miller, P. E. Whitfield, and J. A. Hare. 2004. Thermal tolerance and potential distribution of invasive lionfish (Pterois volitans/miles complex) on the east coast of the United States. Marine Ecology Progress Series 283:269-278. http://dx.doi. org/10.3354/meps 283269

Lakoff, G. 1993. The contemporary theory of metaphor. Pages 202-251 in A. Ortony, editor. Metaphor and thought. Second edition. Cambridge University Press, Cambridge, UK. http://dx. doi.org/10.1017/CBO9781139173865.013

Lambert, B. 2006. A spiny invader proliferates in L.I. waters, and scientists wonder about its impact. New York Times, 08 September. [online] URL: http://www.nytimes.com/2006/09/08/ nyregion/08fish.html

Larson, B. 2008. Entangled biological, cultural and linguistic origins of the war on invasive species. Body, Language and Mind 2:169-196.

Larson, B. M. H. 2005. The war of the roses: demilitarizing invasion biology. Frontiers in Ecology and the Environment 3 (9):495-500. http://dx.doi.org/10.1890/1540-9295(2005)003[0495: twotrd $] 2.0 . \mathrm{co} ; 2$

Larson, B. M. H. 2007a. An alien approach to invasive species: objectivity and society in invasion biology. Biological Invasions 9 (8):947-956. http://dx.doi.org/10.1007/s10530-007-9095-Z

Larson, B. M. H. 2007b. Who's invading what? Systems thinking about invasive species. Canadian Journal of Plant Science 87 (5):993-999. http://dx.doi.org/10.4141/CJPS07116

Larson, B. M. H., B. Nerlich, and P. Wallis. 2005. Metaphors and biorisks the war on infectious diseases and invasive species. 
Science Communication 26(3):243-268. http://dx.doi. org/10.1177/1075547004273019

Lavoie, C. 2010. Should we care about purple loosestrife? The history of an invasive plant in North America. Biological Invasions 12(7):1967-1999. http://dx.doi.org/10.1007/s10530-009-9600-7

Lesser, M. P., and M. Slattery. 2011. Phase shift to algal dominated communities at mesophotic depths associated with lionfish (Pterois volitans) invasion on a Bahamian coral reef. Biological Invasions 13(8):1855-1868. http://dx.doi.org/10.1007/s10530-011-0005$\underline{\mathrm{Z}}$

Linendoll, K. 2013. Lionfish infestation in Atlantic Ocean a growing epidemic. CNN, 19 October. [online] URL: http://www. cnn.com/2013/10/18/tech/innovation/lionfish-infestation-atlanticlinendoll/index.html

Maasen, S., E. Mendelsohn, and P. Mendelsohn, editors. 2001. Biology as society, society as biology: metaphors. Springer, Dordrecht, The Netherlands. http://dx.doi.org/10.1007/978-94-011-0673-3

Mack, R. N., D. Simberloff, M. W. Lonsdale, H. Evans, M. Clout, and F. A. Bazzaz. 2000. Biotic invasions: causes, epidemiology, global consequences, and control. Ecological Applications 10 (3):689-710. http://dx.doi.org/10.1890/1051-0761(2000)010[0689: bicegc]2.0.co:2

Maljković, A., T. Van Leeuwen, and S. N. Cove. 2008. Predation on the invasive red lionfish, Pterois volitans (Pisces: Scorpaenidae), by native groupers in the Bahamas. Coral Reefs 27(3):501-501. http://dx.doi.org/10.1007/s00338-008-0372-9

Márquez, H. 2009. New pirate of the Caribbean invades from Pacific. Inter Press Service News Agency, 02 December. [online] URL: http://www.ipsnews.net/2009/12/environment-new-pirateof-the-caribbean-invades-from-pacificl

Marshall, N. A., M. Friedel, R. D. Van Klinken, and A. C. Grice. 2011. Considering the social dimension of invasive species: the case of buffel grass. Environmental Science \& Policy 14(3):327-338. http://dx.doi.org/10.1016/j.envsci.2010.10.005

McGeoch, M. A., S. H. Butchart, D. Spear, E. Marais, E. J. Kleynhans, A. Symes, J. Chanson, and M. Hoffmann. 2010. Global indicators of biological invasion: species numbers, biodiversity impact and policy responses. Diversity and Distributions 16(1):95-108. http://dx.doi.org/10.1111/ j.1472-4642.2009.00633.x

Messing, R. H., and M. G. Wright. 2006. Biological control of invasive species: solution or pollution? Frontiers in Ecology and the Environment 4(3):132-140. http://dx.doi.org/10.1890/1540-9295 (2006)004[0132:BCOISS]2.0.CO;2

Miami Herald. 2008. Newcomer to Keys is unwelcome, uncouth. Miami Herald, 18 January.

Miloslavich, P., J. M. Díaz, E. Klein, J. J. Alvarado, C. Díaz, J. Gobin, E. Escobar-Briones, J. J. Cruz-Motta, E. Weil, J. Cortes, et al. 2010. Marine biodiversity in the Caribbean: regional estimates and distribution patterns. PLoS One 5(8):e11916. http:// dx.doi.org/10.1371/journal.pone.0011916

Molina, B. 2009. Pez León: se busca vivo o muerto. Mundo Náutico, 24 March. [online] URL: http://www.revistamundonautico. com/pez-leon-se-busca-vivo-o-muerto/
Moore, A. 2012. The aquatic invaders: marine management figuring fishermen, fisheries, and lionfish in the Bahamas. Cultural Anthropology 27(4):667-688. http://dx.doi.org/10.1111/ j.1548-1360.2012.01166.X

Morell, V. 2010. Mystery of the lionfish: don't blame Hurricane Andrew. ScienceInsider, 29 April. [online] URL: http://news. sciencemag.org/2010/04/mystery-lionfish-dont-blame-hurricane$\underline{\text { andrew }}$

Morris, J. A., Jr., editor. 2012. Invasive lionfish: a guide to control and management. Special Publication Series Number 1. Gulf and Caribbean Fisheries Institute, Marathon, Florida, USA.

Morris, J. A., Jr., and J. L. Akins. 2009. Feeding ecology of invasive lionfish (Pterois volitans) in the Bahamian archipelago. Environmental Biology of Fishes 86(3):389-398. http://dx.doi. org/10.1007/s10641-009-9538-8

Morris, J. A., Jr., A. Thomas, A. L. Rhyne, N. Breen, L. Akins, and B. Nash. 2011. Nutritional properties of the invasive lionfish: a delicious and nutritious approach for controlling the invasion. Aquaculture, Aquarium, Conservation \& Legislation 5:99-102.

Morris, J. A., Jr., and P. E. Whitfield. 2009. Biology, ecology, control and management of the invasive Indo-Pacific lionfish: an updated integrated assessment. National Oceanic and Atmospheric Administration (NOAA) Technical Memorandum NOS NCCOS, 99. NOAA/National Ocean Service/Center for Coastal Fisheries and Habitat Research, Beaufort, North Carolina, USA.

Mumby, P. J., D. R. Brumbaugh, A. R. Harborne, and G. Roff. 2013. On the relationship between native grouper and invasive lionfish in the Caribbean. PeerJ PrePrints 1:e45v1 https://dx.doi. org/10.7287/peerj.preprints.45v1.

Mumby, P. J., A. R. Harborne, and D. R. Brumbaugh. 2011. Grouper as a natural biocontrol of invasive lionfish. PLoS One 6(6):e21510. http://dx.doi.org/10.1371/journal.pone.0021510

Nature Foundation. 2011. Nature Foundation recommends population not eat lionfish; study shows toxins found in lionfish caught in St. Maarten waters. St. Maarten Island Time, 21 November. [online] URL: http://sxmislandtime.com/component/ k2/item/16465-nature-foundation-recommends-population-not-eatlionfish-study-shows-toxins-found-in-lionfish-caught-in-st-maartenwaters.html

Nerlich, B., and R. James. 2009. "The post-antibiotic apocalypse" and the "war on superbugs": catastrophe discourse in microbiology, its rhetorical form and political function. Public Understanding of Science 18(5):574-590. http://dx.doi. org/10.1177/0963662507087974

National Oceanic and Atmospheric Administration (NOAA). 2011. National Ocean Service (NOS) education. [online] URL: http://oceanservice.noaa.gov/education/

Nuñez, M. A., S. Kuebbing, R. D. Dimarco, and D. Simberloff. 2012. Invasive species: to eat or not to eat, that is the question. Conservation Letters 5(5):334-341. http://dx.doi.org/10.1111/ j.1755-263x.2012.00250.x

Olsen, E. 2010. Florida Keys declare open season on the invasive Lionfish. New York Times, 22 November. [online] URL: http:// www.nytimes.com/2010/11/23/science/23lionfish.html 
Padilla, D. K., and S. L. Williams. 2004. Beyond ballast water: aquarium and ornamental trades as sources of invasive species in aquatic ecosystems. Frontiers in Ecology and the Environment 2 (3):131-138. http://dx.doi.org/10.1890/1540-9295(2004)002[0131: bbwaao]2.0.co;2

Pan, Z., and G. M. Kosicki. 1993. Framing analysis: an approach to news discourse. Political Communication 10(1):55-75. http://dx. doi.org/10.1080/10584609.1993.9962963

Parker, I. M., D. Simberloff, W. M. Lonsdale, K. Goodell, M. Wonham, P. M. Kareiva, M. H. Williamson, B. Von Holle, P. B. Moyle, J. E. Byers, et al. 1999. Impact: toward a framework for understanding the ecological effects of invaders. Biological Invasions 1(1):3-19. http://dx.doi.org/10.1023/A:1010034312781

Peretti, J. H. 1998. nativism and nature: rethinking biological invasion. Environmental Values 7(2):183-192. http://dx.doi. org/10.3197/096327198129341537

Perry, D., and G. Perry. 2008. Improving interactions between animal rights groups and conservation biologists. Conservation Biology 22(1):27-35. http://dx.doi.org/10.1111/j.1523-1739.2007.00845. $\underline{\mathrm{x}}$

Pickrell, J. 2004. Freed pet fish threaten native species, study says. National Geographic News, 01 June. [online] URL: http://news. nationalgeographic.com/news/2004/05/0520 040520_aquariumescapees. $\underline{\mathrm{html}}$

Pimentel, D., R. Zuniga, and D. Morrison. 2005. Update on the environmental and economic costs associated with alien-invasive species in the United States. Ecological Economics 52(3):273-288. http://dx.doi.org/10.1016/j.ecolecon.2004.10.002

Pimiento, C., E. Monaco, A. B. Barbour, and B. R. Silliman. 2013. Predation on speared red lionfish, Pterois volitans, by spotted moray, Gymnothorax moringa. Florida Scientist 76(3-4):391-394.

Radio Nederland Wereldomroep. 2010. Fighting lionfish necessary for coral [title translated from the Dutch Bestrijding lionfish noodzakelijk voor koraal]. Radio Nederland Wereldomroep, 01 June.

Ricciardi, A., and J. Cohen. 2007. The invasiveness of an introduced species does not predict its impact. Biological Invasions 9(3):309-315. http://dx.doi.org/10.1007/s10530-006-9034-4

Richardson, D. M., P. Pyšek, M. Rejmánek, M. G. Barbour, F. D. Panetta, and C. J. West. 2000. Naturalization and invasion of alien plants: concepts and definitions. Diversity and Distributions 6(2):93-107. http://dx.doi.org/10.1046/j.1472-4642.2000.00083.x

Robbins, P. 2004. Comparing invasive networks: cultural and polictical biographies of invasive species. Geographical Review 94 (2):139-156. http://dx.doi.org/10.1111/j.1931-0846.2004.tb00164. $\underline{\mathrm{X}}$

Robertson, A., A. C. Garcia, H. A. F. Quintana, T. B. Smith, B. F. Castillo, II, K. Reale-Munroe, J. A. Gulli, D. A. Olsen, J. I. Hooe-Rollman, E. L. E. Jester, B. J. Klimek, and S. M. Plakas. 2013. Invasive lionfish (Pterois volitans): a potential human health threat for ciguatera fish poisoning in tropical waters. Marine Drugs 12(1):88-97. http://dx.doi.org/10.3390/md12010088
Rosenthal, E. 2011. Answer for invasive species: put it on a plate and eat it. New York Times, 09 July. [online] URL: http://www. nytimes.com/2011/07/10/science/earth/10fish.html

Ruiz-Carus, R., R. E. Matheson, Jr., D. E. Roberts, Jr., and P. E. Whitfield. 2006. The western Pacific red lionfish, Pterois volitans (Scorpaenidae), in Florida: evidence for reproduction and parasitism in the first exotic marine fish established in state waters. Biological Conservation 128(3):384-390. http://dx.doi.org/10.1016/ j.biocon.2005.10.012

Safina, C. 2012a. Scourge of the lionfish, part 3: the newest fish in the kitchen. New York Times, 10 September. [online] URL: http://bittman.blogs.nytimes.com/2012/09/10/scourge-of-the-lionfishpart-3-the-newest-fish-in-the-kitchen/

Safina, C. $2012 b$. Scourge of the lionfish, part 4: from beautiful novelty to marine invader. New York Times, 18 September. [online] URL: http://coastalscience.noaa.gov/news/coastal-pollution/scourgeof-the-lionfish-part-4-from-beautiful-novelty-to-marine-invader/

Sagoff, M. 2005. Do non-native species threaten the natural environment? Journal of Agricultural and Environmental Ethics 18 (3):215-236. http://dx.doi.org/10.1007/s10806-005-1500-y

Schofield, P. J. 2009. Geographic extent and chronology of the invasion of non-native lionfish (Pterois volitans [Linnaeus 1758] and P. miles [Bennett 1828]) in the Western North Atlantic and Caribbean Sea. Aquatic Invasion 4(3):473-479. http://dx.doi. org/10.3391/ai.2009.4.3.5

Schofield, P. J. 2010. Update on geographic spread of invasive lionfishes (Pterois volitans [Linnaeus, 1758] and P. miles [Bennett, 1828]) in the Western North Atlantic Ocean, Caribbean Sea and Gulf of Mexico. Aquatic Invasion 5(suppl 1):S117-S122. http:// dx.doi.org/10.3391/ai.2010.5.S1.024

Schofield, P. J., J. A. Morris, Jr., J. N. Langston, and P. L. Fuller. 2015. Pterois volitans/miles. USGS Nonindigenous Aquatic Species Database, Gainesville, Florida, USA. [online] URL: http://nas.er.usgs.gov/queries/FactSheet.aspx?speciesID $=963$

Schultz, E. T. 1986. Pterois volitans and Pterois miles: two valid species. Copeia 3:686-690. http://dx.doi.org/10.2307/1444950

Schüttler, E., R. Rozzi, and K. Jax. 2011. Towards a societal discourse on invasive species management: a case study of public perceptions of mink and beavers in Cape Horn. Journal for Nature Conservation 19(3):175-184. http://dx.doi.org/10.1016/j.jnc.2010.12.001

Scyphers, S. B., S. P. Powers, J. L. Akins, J. M. Drymon, C. W. Martin, Z. H. Schobernd, P. J. Schofield, R. L. Shipp, and T. S. Switzer. 2014. The role of citizens in detecting and responding to a rapid marine invasion [early view]. Conservation Letters http:// dx.doi.org/10.1111/conl.12127

Semmens, B. X., E. R. Buhle, A. K. Salomon, and C. V. PattengillSemmens. 2004. A hotspot of non-native marine fishes: evidence for the aquarium trade as an invasion pathway. Marine Ecology Progress Series 266(1):239-244. http://dx.doi.org/10.3354/ $\underline{\text { meps } 266239}$

Shine, R., and J. S. Doody. 2011. Invasive species control: understanding conflicts between researchers and the general community. Frontiers in Ecology and the Environment 9 (7):400-406. http://dx.doi.org/10.1890/100090 
Shogren, E. 2013. Lionfish attacking Atlantic ocean like a living oil spill. WLRN, 17 April. [online] URL: http://wlrn.org/post/ invasive-species-hungry-lionfish-havent-gone-away

Sian Ka'an Biosphere Reserve 2010. Pez león, red lionfish (Pterois sp). A new threat for the Mesoamerican Reef [Title translated from the Spanish "Una nueva amenaza para el arrecife mesoamericano"]. 13 January. [online] URL: http://www. siankaantours.com/page/2/

Silk, R. 2012. FDA wavers on ciguatera warning. Florida Keys News, 30 June. [online] URL: http://keysnews.com/node/40782

Simberloff, D. 2003. Confronting introduced species: a form of xenophobia? Biological Invasions 5(3):179-192. http://dx.doi. org/10.1023/A:1026164419010

Simberloff, D. 2005. non-native species DO threaten the natural environment! Journal of Agricultural and Environmental Ethics 18 (6):595-607. http://dx.doi.org/10.1007/s10806-005-2851-0

Soulé, M. E. 1990. The onslaught of alien species, and other challenges in the coming decades. Conservation Biology 4 (3):233-240. http://dx.doi.org/10.1111/j.1523-1739.1990.tb00283. $\underline{\mathrm{X}}$

Spalburg, J. 2014. Lionfish may have natural predator in the Caribbean. Saba-News, 9 January. [online] URL: http://www. saba-news.com/lionfish-may-natural-predator-caribbean/

Spalding, M. D., H. E. Fox, G. R. Allen, N. Davidson, Z. A. Ferdaña, M. Finlayson, B. S. Halpern, M. A. Jorge, A. Lombana, S. A. Lourie, et al. 2007. Marine ecoregions of the world: a bioregionalization of coastal and shelf areas. BioScience 57 (7):573-583. http://dx.doi.org/10.1641/b570707

Stromberg, J. C., M. K. Chew, P. L. Nagler, and E. P. Glenn. 2009. Changing perceptions of change: the role of scientists in Tamarix and river management. Restoration Ecology 17(2):177-186. http:// dx.doi.org/10.1111/j.1526-100x.2008.00514.x

Subramaniam, B. 2001. The aliens have landed! Reflections on the rhetoric of biological invasions. Meridians: Feminism, Race, Transnationalism 2(1):26-40.

Talbot, R. 2014. Is a ban on lionfish in Florida justified? Coral Magazine 11(4):9-12.

Valdivia, A., J. F. Bruno, C. E. Cox, S. Hackerott, and S. J. Green. 2014. Re-examining the relationship between invasive lionfish and native grouper in the Caribbean. PeerJ PrePrints 2:e262v1. https://dx.doi.org/10.7287/peerj.preprints.262v1 http://dx.doi.org/10.7717/ peerj. 348

Valéry, L., H. Fritz, J.-C. Lefeuvre, and D. Simberloff. 2008. In search of a real definition of the biological invasion phenomenon itself. Biological Invasions 10(8):1345-1351. http://dx.doi. org/10.1007/s10530-007-9209-7

Vitousek, P. M., C. M. D'Antonio, L. L. Loope, and R. Westbrooks. 1996. Biological invasions as global environmental change. American Scientist 84(5):468-478.

Warren, C. R. 2007. Perspectives on the 'alien ' versus 'native' species debate: a critique of concepts, language and practice. Progress in Human Geography 31(4):427-446. http://dx.doi. org/10.1177/0309132507079499
Weeks, P., and J. Packard. 2009. Feral hogs: invasive species or nature's bounty? Human Organization 68(3):280-292. http://dx. doi.org/10.17730/humo.68.3.663wn82g164321u1

Wetherell, M., S. Taylor, and S. J. Yates. 2001. Discourse as data: a guide for analysis. Sage, London, UK.

Whitfield, P. E., T. Gardner, S. P. Vives, M. R. Gilligan, W. R. Courtenay, Jr., G. C. Ray, and J. A. Hare. 2002. Biological invasion of the Indo-Pacific lionfish Pterois volitans along the Atlantic coast of North America. Marine Ecology Progress Series 235:289-297. http://dx.doi.org/10.3354/meps235289

Whitfield, P. E., J. A. Hare, A. W. David, S. L. Harter, R. C. Muñoz, and C. M. Addison. 2007. Abundance estimates of the Indo-Pacific lionfish Pterois volitans/miles complex in the Western North Atlantic. Biological Invasions 9(1):53-64. http://dx.doi. org/10.1007/s10530-006-9005-9

Wilcove, D. S., D. Rothstein, J. Dubow, A. Phillips, and E. Losos. 1998. Quantifying threats to imperiled species in the United States. BioScience 48(8):607-615. http://dx.doi.org/10.2307/1313420

Wilcox, C. L., and M. A. Hixon. 2014. False positive tests for ciguatera may derail efforts to control invasive lionfish. Environmental Biology of Fishes 98(3):961-969. https://dx.doi. org/10.1007/s10641-014-0313-0 http://dx.doi.org/10.1007/ $\underline{\mathrm{s} 10641-014-0313-0}$

WSJ Video. 2010. U.S. coast battles the lionfish. Wall Street Journal Online, 15 August. [online] URL: http://www.wsj.com/ video/us-coast-battles-the-lionfish/73E6AF75-1999-4C6DBEB7-44B8C788C57F.html

Wong, W. Y. 2002. The scientific and media discourse of biological invasion. Brown University, Providence, Rhode Island, USA.

WPBT. 2011. Changing seas, alien invaders. WBPT, 7 June. [online] URL: http://video.wpbt2.org/video/1979166369/

Wu, J., and O. L. Loucks. 1995. From balance of nature to hierarchical patch dynamics: a paradigm shift in ecology. Quarterly Review of Biology 70(4):439-466. http://dx.doi. org/10.1086/419172

Young, A. M., and B. M. H. Larson. 2011. Clarifying debates in invasion biology: a survey of invasion biologists. Environmental Research 111(7):893-898. http://dx.doi.org/10.1016/j.envres.2011.06.006

Zinken, J. 2007. Discourse metaphors: the link between figurative language and habitual analogies. Cognitive Linguistics 18 (3):445-466. http://dx.doi.org/10.1515/cog.2007.024 


\section{Appendix 1.}

Primary data sources: interviews with MPA stakeholders (January-March 2013).

\begin{tabular}{|c|c|c|}
\hline $\begin{array}{c}\text { MPA } \\
\text { location }\end{array}$ & Affiliation, profession & $\begin{array}{c}\text { Interview mode } \\
\text { (Tel.: T, Face-to- } \\
\text { face: F, } \\
\text { Email: E) }\end{array}$ \\
\hline \multirow{8}{*}{$\begin{array}{l}\text { Florida } \\
\text { Keys }\end{array}$} & Commercial fishing (aquarium industry) & $\mathrm{T}$ \\
\hline & Recreational fisher (angler) & $\mathrm{T}$ \\
\hline & Artificial reef industry / recreational fishing & $\mathrm{T}$ \\
\hline & MPA staff (NOAA) & $\mathrm{T}$ \\
\hline & REEF (NGO) & $\mathrm{T}$ \\
\hline & Marine Science lecturer \& recreational diver & $\mathrm{T}$ \\
\hline & The Nature Conservancy (NGO) & $\mathrm{E}$ \\
\hline & Florida Fish and Wildlife Conservation Commission (FWCC) & $\mathrm{E}$ \\
\hline \multirow{3}{*}{$\begin{array}{l}\text { Sian } \\
\text { Ka'an }\end{array}$} & Commercial fishing (president fishing cooperative) & $\mathrm{T}$ \\
\hline & MPA staff (CONANP) & $\mathrm{T}, \mathrm{E}$ \\
\hline & Recreational fishing industry & $\mathrm{E}$ \\
\hline \multirow[t]{10}{*}{ Bonaire } & $\begin{array}{l}\text { Dive operators (managers \& instructors) } \\
\text { Total: } 15 \text { individuals from } 12 \text { different dive shops }\end{array}$ & $\mathrm{F}$ \\
\hline & Scientist (CIEE) & $\mathrm{F}$ \\
\hline & MPA staff (STINAPA) Total: 3 individuals & $\mathrm{F}$ \\
\hline & Local government, senior official & $\mathrm{F}$ \\
\hline & Local government, junior official & $\mathrm{F}$ \\
\hline & Local government (Dutch Caribbean level), senior official & $\mathrm{F}$ \\
\hline & Dutch Caribbean Nature Alliance (NGO) & $\mathrm{F}$ \\
\hline & Educator (teaching scuba at schools) & $\mathrm{F}$ \\
\hline & $\begin{array}{l}\text { Retiree, recreational diver } \\
\text { Total: } 7 \text { individuals }\end{array}$ & $\mathrm{F}$ \\
\hline & Retiree, recreational diver & $\mathrm{E}$ \\
\hline \multirow[t]{6}{*}{ Curaçao } & $\begin{array}{l}\text { Dive operators (managers } \& \text { instructors) } \\
\text { Total: } 8 \text { individuals from } 6 \text { different dive shops }\end{array}$ & $\mathrm{F}$ \\
\hline & Restaurant owner, dive instructor & $\mathrm{F}$ \\
\hline & Local government, senior official & $\mathrm{F}$ \\
\hline & Coast guard, senior official & $\mathrm{F}$ \\
\hline & Coast guard, junior official & $\mathrm{F}$ \\
\hline & Scientist CARMABI & $\mathrm{F}$ \\
\hline \multirow[t]{2}{*}{ Saba } & $\begin{array}{l}\text { Dive operators (managers } \& \text { instructors) } \\
\text { Total: } 4 \text { individuals from } 3 \text { different dive shops }\end{array}$ & $\mathrm{F}$ \\
\hline & MPA staff (Saba Conservation Foundation) & $\mathrm{F}$ \\
\hline \multirow{3}{*}{$\begin{array}{l}\text { St. } \\
\text { Eustatius }\end{array}$} & MPA staff (STENAPA) Total: 3 individuals & $\mathrm{F}$ \\
\hline & $\begin{array}{l}\text { Dive operators (managers \& instructors) } \\
\text { Total: } 4 \text { individuals from } 2 \text { different dive shops }\end{array}$ & $\mathrm{F}$ \\
\hline & Commercial fishing (president fisheries association) & $\mathrm{F}$ \\
\hline \multirow{2}{*}{$\begin{array}{l}\text { St. } \\
\text { Maarten }\end{array}$} & MPA staff (The Nature Foundation) & $\mathrm{F}$ \\
\hline & $\begin{array}{l}\text { Dive operators (managers } \& \text { instructors) } \\
\text { Total: } 10 \text { individuals from } 6 \text { different dive shops }\end{array}$ & $\mathrm{F}$ \\
\hline
\end{tabular}




\section{Appendix 2.}

\section{Interview schedule}

Topics were adapted to the individual respondent according to his/her function or profession in the MPA. By asking respondents to provide their "views", "perceptions" or "perspectives" about lionfish (LF) presence in MPA's waters - and about LF management in their MPAs- the meanings they attach to LF could be explored broadly. Probing questions attempted to elicit more specific responses.

\section{$\underline{\text { Introduction }}$}

Q: I would like to start by asking if you could describe your daily activities related to (MPA). Q: In your daily life, how often do you have to do in any way with LF? For example, during work or recreational activities.

\section{$\underline{\text { Origin }}$}

Q: How/when did you hear about the LF for the first time? Probing: Please describe the time when the first LF were sighted in (MPA). What type of information did you receive and from which source?

\section{$\underline{\text { Spread }}$}

Q: In your view, are LF numbers (in MPA) increasing, decreasing or stable? Probing: How often do you go in the water? When you are in the water, how often do you see LF? When you see LF, what do you do and why? Q: Is LF monitoring carried out in (MPA)?

\section{$\underline{\text { Impact }}$}

Q: I would like to hear your perspectives/perceptions/views about LF (in general and specifically in MPA). Q: What is your perception about the LF in terms of affecting your activities, your business, your health? Probing: I would like to have a general idea of what's going on at (MPA) regarding LF; how do you and your colleagues interact with LF; you say that personally you do/not encounter LF and/but you know that they're having an impact, could you elaborate? Q: Have you (or someone you know) been stung by a LF? How does it feel like? How did it happen?

\section{$\underline{\text { Control }}$}

Q: How is LF managed in (MPA)? Probing: Who participates and how? What do you think about the way LF is managed in (MPA)? Q: Have you ever captured a LF? Why/not? Probing: Who are the main groups involved in management? Do you need a permit to capture LF? Where is LF capture allowed in (MPA)? With what kind of gear? Is there sustained interest in LF tournaments/derbies? In LF workshops/trainings (required to apply for a capture permit in Florida Keys)?

Q: What can you tell me about the commercialization of LF? Probing: Have you eaten LF? Do you like it? How does it taste like? Who is harvesting LF commercially? Who is not, and why? How many LF are harvested for consumption? What do you think about this development? What can you tell me about ciguatera risk in (MPA)? 